\title{
A Mixture of Endocrine Disrupting Chemicals Associated with Lower Birth Weight in Children Induces Adipogenesis and DNA Methylation Changes in Human Mesenchymal Stem Cells
}

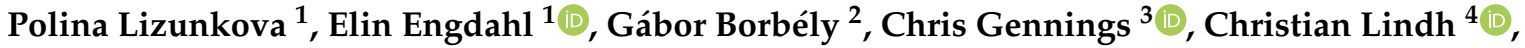 \\ Carl-Gustaf Bornehag ${ }^{3,5}$ and Joëlle Rüegg ${ }^{1, *}$
}

Citation: Lizunkova, P.; Engdahl, E.; Borbély, G.; Gennings, C.; Lindh, C.;

Bornehag, C.-G.; Rüegg, J. A Mixture of Endocrine Disrupting Chemicals Associated with Lower Birth Weight in Children Induces Adipogenesis and DNA Methylation Changes in Human Mesenchymal Stem Cells. Int. J. Mol. Sci. 2022, 23, 2320. https:// doi.org/10.3390/ijms23042320

Academic Editor: Guido R. M. M. Haenen

Received: 25 January 2022

Accepted: 17 February 2022

Published: 19 February 2022

Publisher's Note: MDPI stays neutral with regard to jurisdictional claims in published maps and institutional affiliations.

Copyright: (C) 2022 by the authors. Licensee MDPI, Basel, Switzerland. This article is an open access article distributed under the terms and conditions of the Creative Commons Attribution (CC BY) license (https:// creativecommons.org/licenses/by/ $4.0 /)$
1 Department of Organismal Biology, Uppsala University, 75236 Uppsala, Sweden; polina.lizunkova@ebc.uu.se (P.L.); elin.engdahl@ebc.uu.se (E.E.)

2 The Swedish Toxicology Sciences Research Center (Swetox), 15257 Södertälje, Sweden; gab.borbely@gmail.com

3 Department of Environmental Medicine and Public Health, Icahn School of Medicine at Mount Sinai, New York, NY 10029, USA; chris.gennings@mssm.edu (C.G.); carl-gustaf.bornehag@kau.se (C.-G.B.)

4 Occupational and Environmental Medicine, Lund University, 22363 Lund, Sweden; christian.lindh@med.lu.se

5 Department of Health Sciences, Karlstad University, 65188 Karlstad, Sweden

* Correspondence: joelle.ruegg@ebc.uu.se; Tel.: +46-73-7121592

\begin{abstract}
Endocrine Disrupting Chemicals (EDCs) are man-made compounds that alter functions of the endocrine system. Environmental mixtures of EDCs might have adverse effects on human health, even though their individual concentrations are below regulatory levels of concerns. However, studies identifying and experimentally testing adverse effects of real-life mixtures are scarce. In this study, we aimed at evaluating an epidemiologically identified EDC mixture in an experimental setting to delineate its cellular and epigenetic effects. The mixture was established using data from the Swedish Environmental Longitudinal Mother and child Asthma and allergy (SELMA) study where it was associated with lower birth weight, an early marker for prenatal metabolic programming. This mixture was then tested for its ability to change metabolic programming of human mesenchymal stem cells. In these cells, we assessed if the mixture induced adipogenesis and genome-wide DNA methylation changes. The mixture increased lipid droplet accumulation already at concentrations corresponding to levels measured in the pregnant women of the SELMA study. Furthermore, we identified differentially methylated regions in genes important for adipogenesis and thermogenesis. This study shows that a mixture reflecting human real-life exposure can induce molecular and cellular changes during development that could underlie adverse outcomes.
\end{abstract}

Keywords: Endocrine Disrupting Chemicals; EDC; chemical mixtures; mesenchymal stem cells; adipogenesis; DNA methylation; low birth weight

\section{Introduction}

Human exposure is omnipresent to chemicals that interfere with the endocrine system; for example, via a variety of consumer products such as clothing, electronics, personal care products, and building material, as well as foods and food-contact materials [1,2]. Numerous studies worldwide have shown the presence of chemicals with proven or suspected endocrine disrupting properties, i.e., Endocrine Disrupting Chemicals (EDCs), in human blood and urine [3,4]. Exposure to EDCs has been associated with, among others, interference with sexual, neurological, and metabolic development in humans and animals [5].

EDC exposure during critical periods of fetal life is of particular concern for growth and metabolic development, as hormonal signaling plays a vital part in, e.g., stem cell differentiation and adipose tissue development [5-10]. The first neonatal measurement of the quality of the foetal growth is birth weight, where low birth weight can indicate foetal 
growth retardation in the intrauterine environment [11-13]. Numerous epidemiological studies have observed an association between low birth weight-when controlling for gestational age-and several diseases that manifest later in life such as obesity, type II diabetes, and cardiovascular diseases [14-17]. We recently reported an inverse association between prenatal exposure to a mixture of five perfluorinated alkyl substances (PFAS) and birth weight of children in the Swedish Environmental Longitudinal, Mother and Child, Asthma and allergy (SELMA) study [18]. This is supported by other studies that have found an inverse association between prenatal exposure to all of the chemicals from this PFAS mixture, as well as between the phthalate mono(2-ethyl-5-hydroxyhexyl) (MEHHP), the organochlorine dichlorodiphenyldichloroethylene ( $p, p^{\prime}$-DDE) and birth weight [19-21]. Additionally, a meta-analysis of 13 European mother-child cohorts found that a maternal occupational exposure to one or more EDC groups, including pesticides, phthalates and organic solvents, resulted in a higher risk of low birth weight of the child [22].

Lower birth weight is indeed an indicator for metabolic changes later in life and is supported by studies demonstrating associations between developmental EDC exposure and metabolic outcomes in children (reviewed, e.g., by Ghassabian et al. [23]). In particular, PFAS have been associated with child adiposity in several cohort studies [24-27]. In the SELMA study, changes in weight trajectories were associated with prenatal exposure to a mixture of EDCs, including PFAS, Triclosan, phthalates, non-phthalate plasticizers, bisphenols, polycyclic aromatic hydrocarbons, pesticides, and polychlorinated biphenyls (PCBs). Huselmman data is supported by ample experimental evidence for changes in metabolic programming induced by developmental exposure to EDCs (reviewed, e.g., by Howard [28]). This combined evidence implicates a potential for later life adverse health effects as a result of adverse changes to metabolic programming induced by EDC exposure during critical periods of development [29-31].

Epigenetic processes play an important role during development, where they direct cell differentiation, as well as tissue and organ development [32-34]. Epigenetics refers to heritable gene expression traits that do not entail DNA sequence alterations [35]. One of the key epigenetic processes is DNA methylation. DNA methylation refers to the addition of a methyl group to the 5-cytosine residue, which can alter, for example, the accessibility of transcription factor binding sites, thereby regulating gene expression. Environmental insults, such as EDC exposure, have been shown to induce epigenetic changes [36]. As epigenetic alterations can be mitotically heritable, and thus persistent over a long period, they might, at least partly, underlie the link between developmental EDC exposure and an individual's susceptibility to metabolic disorders later in life [37-40].

While evidence for harmful effects of single EDCs is accumulating, the fact that human real-life exposures entail complex mixtures of chemicals is largely ignored. Most research studies, as well as risk assessment and chemical regulations, focus on single EDCs in isolation or groups of EDCs from the same chemical class, not reflecting the real-life situation. As a result, effects on human health may be underestimated if the chemical in question is present with several other chemicals that may contribute to the same adverse outcome. Thus, even when individual concentrations of chemicals are below their regulatory thresholds, their simultaneous exposure effects may produce long-lasting health adversities [4,41-43].

One challenge with regard to chemical mixtures is to identify the truly harmful ones among the infinite number of possible mixtures which humans are exposed to. To address this issue, we have previously, in a population-based epidemiological setting, established a whole mixture approach to define human relevant chemical mixtures in pregnant women associated with health outcomes in their children [44].

These mixtures have been further studied in experimental settings [45-47]. In the present study, we evaluated the effects of an EDC mixture associated with lower birth weight (Mix G1) on adipogenesis and DNA methylation patterns in human mesenchymal stem cells (hMSCs). The aim of this approach was to establish correlative evidence for the 
associations observed in the human data, and to delineate molecular events underlying these effects.

\section{Results}

\subsection{Exposure to Human Relevant Concentrations of Mix G1 Induces Adipogenesis in hMSCs}

An epidemiologically defined chemical mixture associated with lower birth weight (Mix G1, composition shown in Table 1) was investigated for its effect on adipogenesis of hMSCs (Figure 1). hMSC differentiation into adipocytes captures an essential part of human adipose tissue development occurring during gestational weeks 14-16 [48,49]. To investigate if Mix G1 induces changes to the adipogenesis potential of hMSCs, bone-marrow derived hMSCs from two donors were exposed to five concentrations of Mix G1 for 3 weeks. Adipogenesis was then measured as lipid droplet accumulation by high content imaging.

Table 1. Individual chemicals within Mix G1.

\begin{tabular}{|c|c|c|c|c|c|}
\hline Chemical Class & $\begin{array}{c}\text { Parent } \\
\text { Compound }^{1}\end{array}$ & $\begin{array}{c}\text { Mix G1 } \\
\text { Compound }^{2}\end{array}$ & Full Compound Name & $\begin{array}{c}\text { Concentration } \\
(\mathrm{nM})^{3}\end{array}$ & CAS Number \\
\hline \multirow[t]{4}{*}{ Phthalates } & DEP & MEP & Monoethyl phthalate & 29.7 & $2306-33-4$ \\
\hline & DBP & MBP & Monobutyl phthalate & 26.4 & $131-70-4$ \\
\hline & $\mathrm{BBzP}$ & MBzP & Monobenzyl phthalate & 5.3 & $2528-16-7$ \\
\hline & DEHP & MEHP & $\begin{array}{l}\text { Mono-(2-ethylhexyl) phthalate } \\
\text { 2-4-Methyl-7-oxyooctyl- }\end{array}$ & 19.0 & $4376-20-9$ \\
\hline \multirow[t]{2}{*}{ Plasticizer } & DiNCH & MINCH & $\begin{array}{l}\text { oxycarbonyl-cyclohexane } \\
\text { carboxylic acid }\end{array}$ & 0.5 & $1588520-62-0$ \\
\hline & TTP & DPP & Diphenylphosphate & 0.5 & $838-85-7$ \\
\hline \multirow{2}{*}{$\begin{array}{l}\text { Antibacterial } \\
\text { PAH }\end{array}$} & & Triclosan & & 0.3 & $3380-34-5$ \\
\hline & & $2 \mathrm{OHPH}$ & 2-Hydroxyphenanthrene & 1.3 & $605-55-0$ \\
\hline \multirow{4}{*}{$\begin{array}{l}\text { Pesticide } \\
\text { PFAS }\end{array}$} & Pyrethroids & 3-PBA & 3-Phenoxybenzoic acid & 0.1 & $3739-38-6$ \\
\hline & & PFOA & Perfluorooctanoic acid & 3.6 & $335-67-1$ \\
\hline & & PFOS & Perfluorooctane sulfonate & 9.7 & $1763-23-1$ \\
\hline & & PFHxS & Perfluorohexane sulfonate & 3.0 & $355-46-4$ \\
\hline \multirow{2}{*}{$\begin{array}{l}\text { Organo-chlorine } \\
\text { pesticide }\end{array}$} & & НСВ & Hexachlorobenzene & 0.1 & $118-74-1$ \\
\hline & DDT & $p, p^{\prime} \mathrm{DDE}$ & Dichlorodiphenyltrichloroethane & 0.5 & $50-29-3$ \\
\hline
\end{tabular}

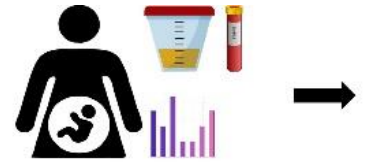

1. 41 compounds were analysed in blood and urine samples of week 10 pregnant mothers.
2. A mixture of 14 analysed compounds Mix G1 - was composed based their association with lower birth weight.
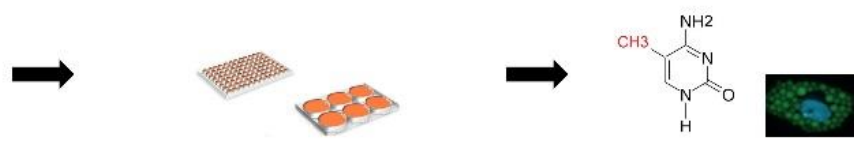

3. Exposure of human mesenchymal stem cells to Mix G1 1X (the same as concentrations measured in the mothers, $100 \mathrm{nM}$ ), as well as Mix G1 0.1X, 10X, 100X, and $1000 \mathrm{X}$.
4. Analysis of lipid droplet accumulation and underlying DNA methylation changes.

Figure 1. Overview of the steps in the study. 1. In the SELMA pregnancy cohort blood and urine samples were collected around pregnancy week 10 for analysis of 41 compounds. A mixture of 14 analysed compounds was associated with lower birth weight. 2. A 1 M stock of this epidemiologically identified EDC mixture (Mix G1), based on the levels and ratios measured in the SELMA samples, was composed in dimethyl sulfoxide (DMSO). 3. In vitro studies were conducted where human mesenchymal stem cells were exposed to Mix G1 at 10 nM (Mix G1 0.1X), 100 nM (Mix G1 1X, 
corresponding to a typical human level based on SELMA data), $1 \mu \mathrm{M}$ (Mix G1 10X), $10 \mu \mathrm{M}$ (Mix G1 100X), $100 \mu \mathrm{M}$ (Mix G1 1000X) in a 3-week long differentiation protocol. 4. Morphological endpoints (adipogenesis measured as lipid droplet accumulation using high content imaging) and underlying epigenetic regulation (Illumina EPIC DNA methylation analysis) were assessed.

As seen in Figure 2, Mix G1 increased lipid droplet accumulation in hMSCs. This increase was significant at the $1 \mathrm{X}$ concentration (i.e., the same levels as the serum mean concentration measured in the SELMA women) and at higher concentrations of Mix G1 (Figure 2). These results suggest that Mix G1, identified to be associated with lower birth weight in epidemiological data, induces changes to the adipogenic potential of hMSCs already at relevant human levels.

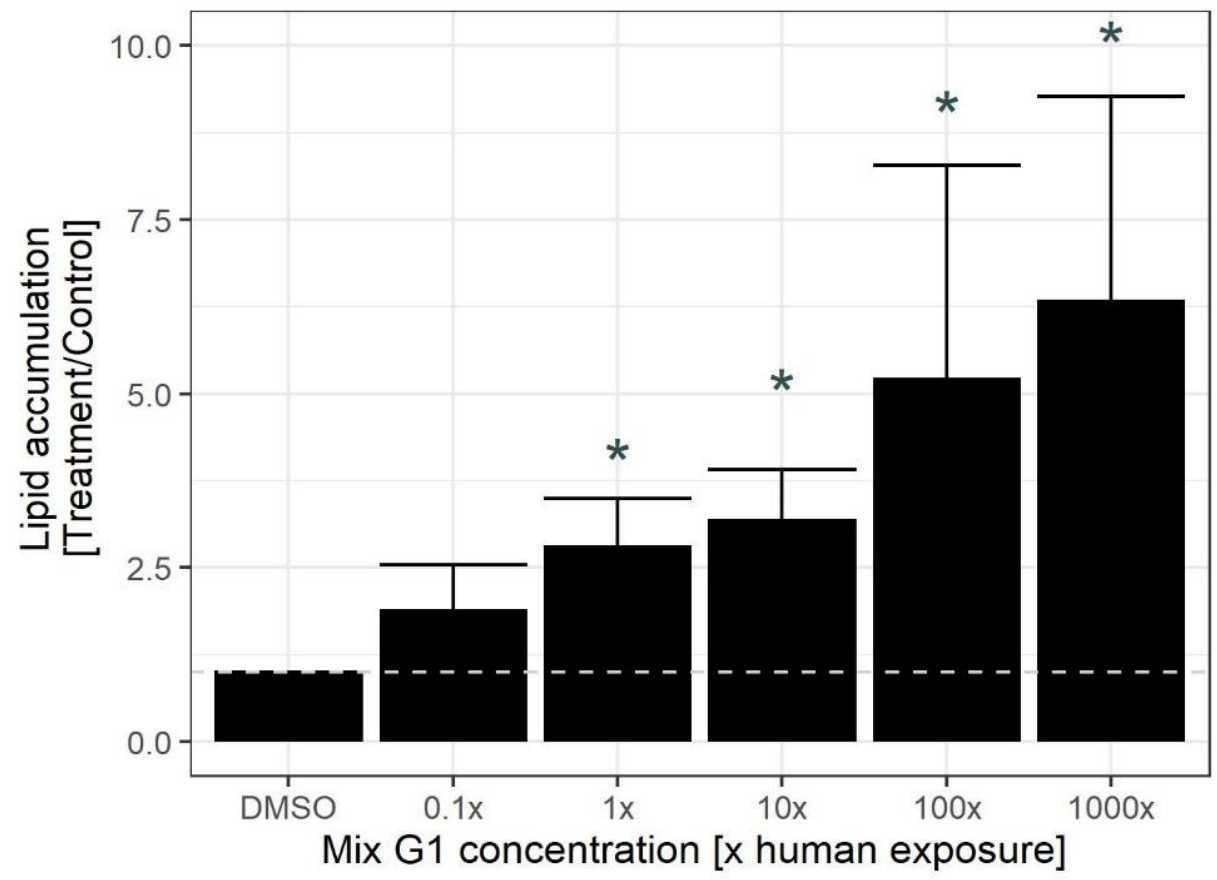

Figure 2. Mix G1-induced lipid droplet accumulation in hMSCs. hMSCs were exposed to 0.1X, 1X, 10X, 100X, 1000X Mix G1 or DMSO for three weeks. Lipids and nuclei were then stained using Bodipy 493/503 and Hoechst 33342, respectively, which were quantified using high content imaging. For each treatment, the lipid accumulation per cell is presented normalized to the lipid accumulation per cell of the DMSO control on the same plate, where mean and standard error per treatment is shown in the graph. ${ }^{*}=p<0.05$ obtained by Kruskal-Wallis rank sum test followed by Dunns post hoc test adjusted with the Benjamini-Hochberg method when comparing with DMSO as a control.

\subsection{Exposure to Human Relevant Concentrations of Mix G1 Induces Altered DNA Methylation Profiles}

To investigate if Mix G1 induces epigenetic changes in hMSCs that could underlie the observed alterations in differentiation, genome-wide DNA methylation patterns were assessed after three weeks' exposure to 1X, 10X, 1000X Mix G1 and DMSO using Illumina Infinium MethylationEPIC BeadChip array. Principal component analysis (PCA) showed that methylation patterns of hMSCs exposed to the lowest (1X) and the highest (1000X) concentrations were similar, and clearly different from the control and 10X Mix G1, indicating a possible non-monotonic effect on methylation (Figure 3A). 

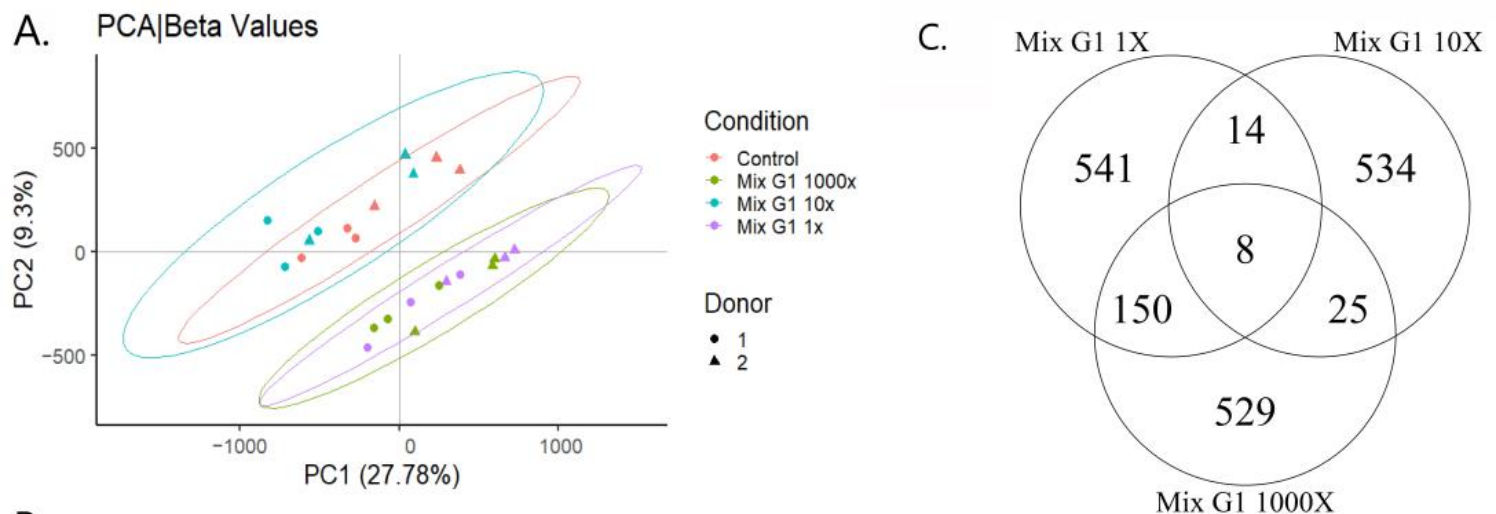

B.
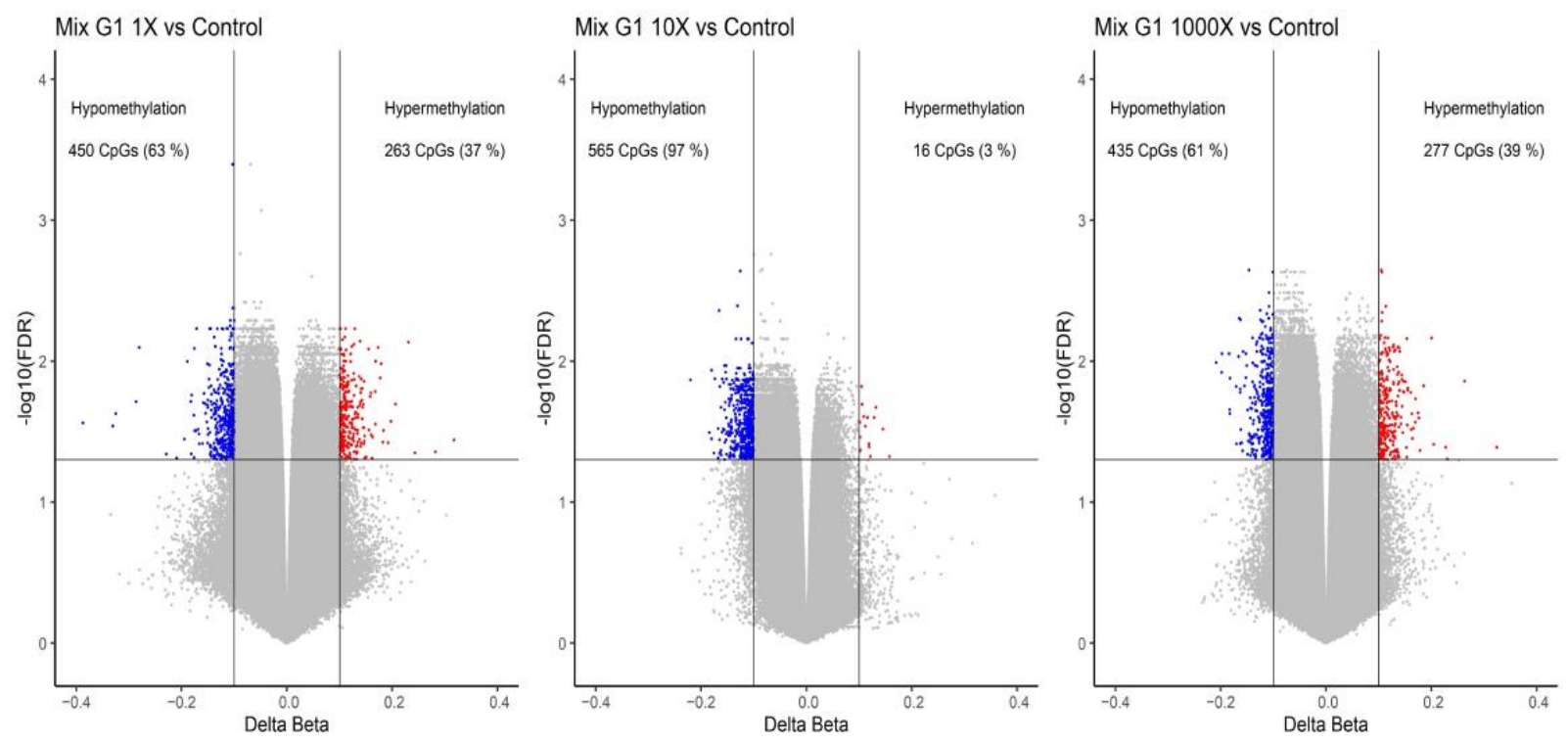

Figure 3. Characteristics of DMPs in hMSCs exposed to three different contractions of Mix G1 (1X, 10X, 1000X) and control (DMSO). (A) Principal component analysis of methylation states of over 850,000 CpGs. hMSCs from Donor 1 are represented as circles; hMSCs from Donor 2 are represented as triangles. Color indicates exposure where purple = Mix G1 1X (i.e., the same as concentrations measured in the SELMA study, $100 \mathrm{nM})$; blue = 10X; green = 1000X; and red = control (1:1000 DMSO). (B) Volcano plot showing - $\log 10$ (FDR) and beta difference compared to the control. DMPs are highlighted in red and blue colors based on horizontal lines indicating threshold for significance $(\mathrm{FDR}=0.05)$ and vertical lines indicate threshold for change in methylation $(-/+10 \% \Delta \beta$ compared to DMSO control). (C) Venn Diagram showing overlapping DMPs among the treatments.

The largest number of differentially methylated positions (DMPs, FDR $<0.05, \Delta \beta>10 \%$ ) were identified in hMSCs exposed to 1X Mix G1 $(n=713)$ (Table S3), followed by the exposure to 1000X $(n=712)$ (Table S3), and the least number of DMPs after exposure to 10X $(n=581)$ (Table S3) (Figure 3B). For all three treatments, the majority of DMPs were hypomethylated. The DMP with the largest methylation change was hypomethylated $(-38.7 \%$; FDR $=0.027)$ in comparison to the control and located in the PUM1 gene after exposure to $1 \mathrm{X}$ concentration. The PUM1 gene is coding for a protein which is known to be involved in hMSCs self-maintenance and proliferation.

As shown in Figure 3C, only 8 identified DMPs were shared among the three treatments. These 8 DMPs were hypomethylated for all treatments, and 4 of them were located in gene regions (CAPN8, NR6A1, SERINC2, C5orf66). Methylation levels of these overlapping DMPs were not affected in a non-monotonic fashion by the mixture but showed rather a threshold response (Figure S1). 
Most DMPs $(n=158)$ were shared between the hMSCs exposed to the $1 \mathrm{X}$ and the 1000X Mix G1 (Table S4). These included hypermethylated DMP annotated to the FGF9, MYOF, ZNRF3, ACSM3, AMN, APBB2, EGFL6, RBMS1, GNAQ, PTPRJ, and TOMM7 genes known to be important for osteogenesis and thermogenesis [50,51], adipogenesis [52], body fat distribution [53], fatty acid metabolism [54,55], obesity [56-58], glucose metabolism [59], type 2 diabetes and insulin signaling [60,61], respectively. Several DMPs were also hypomethylated in the FFAR2, IRS-1, MAF, and PGM1 genes known to be important for lipid accumulation [62], adipocyte differentiation [63,64], and glycogen metabolism and adipogenesis [65,66], respectively.

To evaluate the distribution of DMPs induced by exposures to Mix G1, their location in relation to gene regions and $\mathrm{CpG}$ islands was plotted (Figure S2). Genomic distribution of the hypermethylated and hypomethylated DMPs in comparison to all the CpGs on the Illumina EPIC BeadChip showed enrichment mainly in intergenic regions (IGR), open sea, and shelf regions, while depletion was mainly in $\mathrm{CpG}$ island, shore, and 1st Exon regions.

In summary, exposure to all three concentrations of Mix G1 induced significant DNA methylation changes with more hypo- than hypermethylated DMPs. Most overlap was found to have the lowest and highest concentrations.

\subsection{Differentially Methylated Regions Induced by Mix G1 Treatment Are Linked to Adipogenesis and Metabolic Functions}

As the role for methylation at single CpGs, in particular in intergenic regions, is unclear, we focused our next analysis on identification of differentially methylated regions (DMRs). DMRs are composed of several, often correlated neigbouring DMPs in a specific gene region. As a result, DMRs are more likely to have biological relevance and associations with changes in gene expression than DMPs. Among the freely available tools, Bumphunter is a long-established tool for detection of DMRs. Thus, we conducted Bumphunter analysis for identification of DMRs (family-wise error rate $($ FWER) $<0.20$ ) that are composed of seven or more successive CpGs affected by Mix G1 with a maximum distance of $<300 \mathrm{bp}$ between each other. Six DMRs, annotated to the genes HOXA11AS/HOXA11, PM20D1, PANCR, HOXA5, RP11-134D3.2, and RPL28, were identified to be hypomethylated by Mix G1 1X exposure (FWER < 0.20) (Tables 2 and S5, Figure 4). No DMRs were identified upon exposure to Mix G1 10X. Upon exposure to Mix G1 1000X, two hypomethylated DMRs were identified, which were in the same regions of the HOXA11AS/HOXA11 and PANCR genes as for Mix G1 1X (Figure S3 and Table S6). Expression of HOXA11AS and HOXA5 positively regulates adipocyte differentiations $[67,68]$. While PM20D1 codes for the enzyme PM20D1, a newly identified regulator of thermogenesis and glucose homeostasis [69,70]. Lastly, expression of RPL28 gene has previously been identified to have a negative correlation with BMI [71].

Table 2. Details about the six identified DMRs upon exposure to Mix G1 1X.

\begin{tabular}{ccccccc}
\hline Gene & CHR $^{\mathbf{1}}$ & Start $^{2}$ & End $^{3}$ & Length & $\begin{array}{c}\text { Number } \\
\text { of CpGs }\end{array}$ & FWER $^{\mathbf{4}}$ \\
\hline HOXA11AS/HOXA11 & 7 & $27,224,700$ & $27,226,329$ & 1629 & 28 & 0.096 \\
PM20D1 & 1 & $205,818,484$ & $205,819,609$ & 1125 & 13 & 0.096 \\
PANCR & 16 & $87,101,534$ & $87,102,691$ & 1157 & 11 & 0.12 \\
HOXA5 & 7 & $27,183,643$ & $27,184,853$ & 1210 & 28 & 0.144 \\
RP11-134D3.2 & 4 & $111,532,996$ & $111,533,951$ & 955 & 9 & 0.152 \\
RPL28 & 19 & $55,896,842$ & $55,897,819$ & 977 & 13 & 0.152 \\
\hline
\end{tabular}

${ }^{1} \mathrm{CHR}=$ chromosome. ${ }^{2}$ Start $=$ the start of the DMR region in the Human (GRCh37/hg19) Assembly genome. ${ }^{3}$ End $=$ the end of the DMR region in the Human (GRCh37/hg19) Assembly genome. ${ }^{4}$ FWER = family wise error rate. 


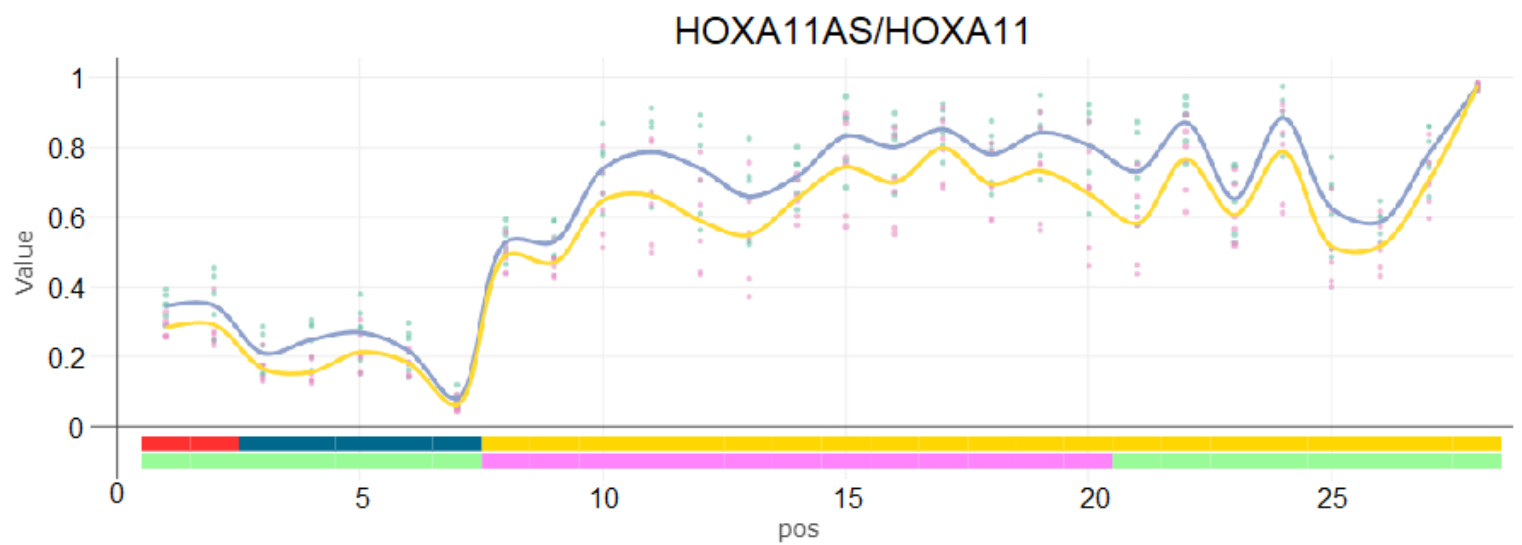

PM20D1

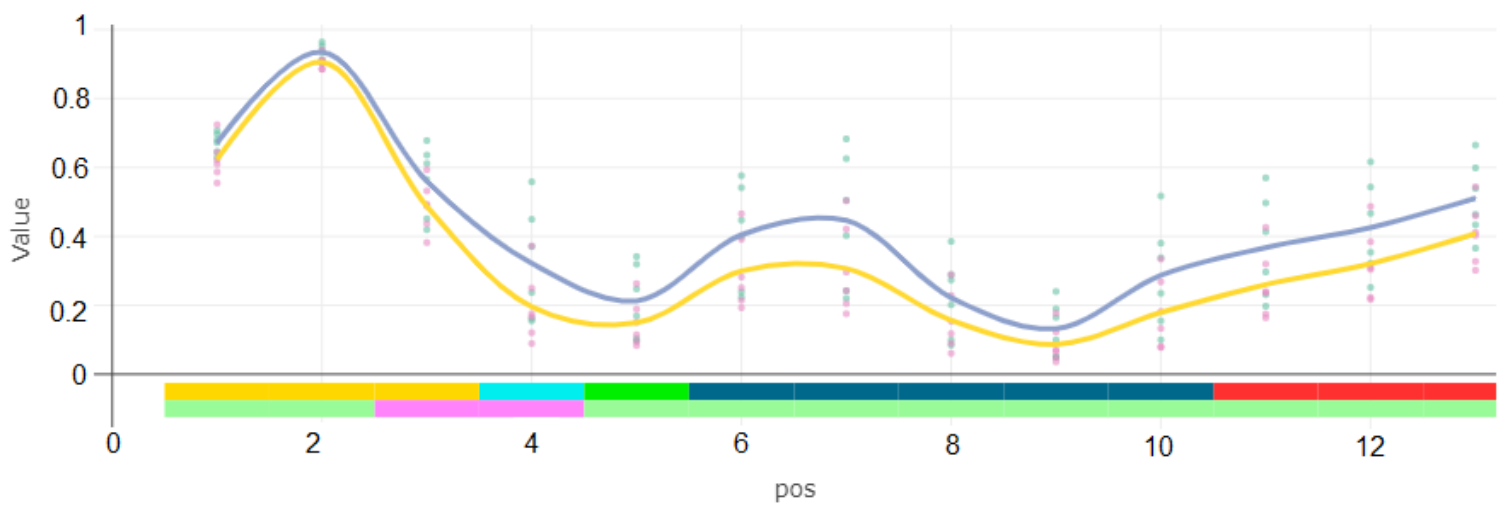

PANCR

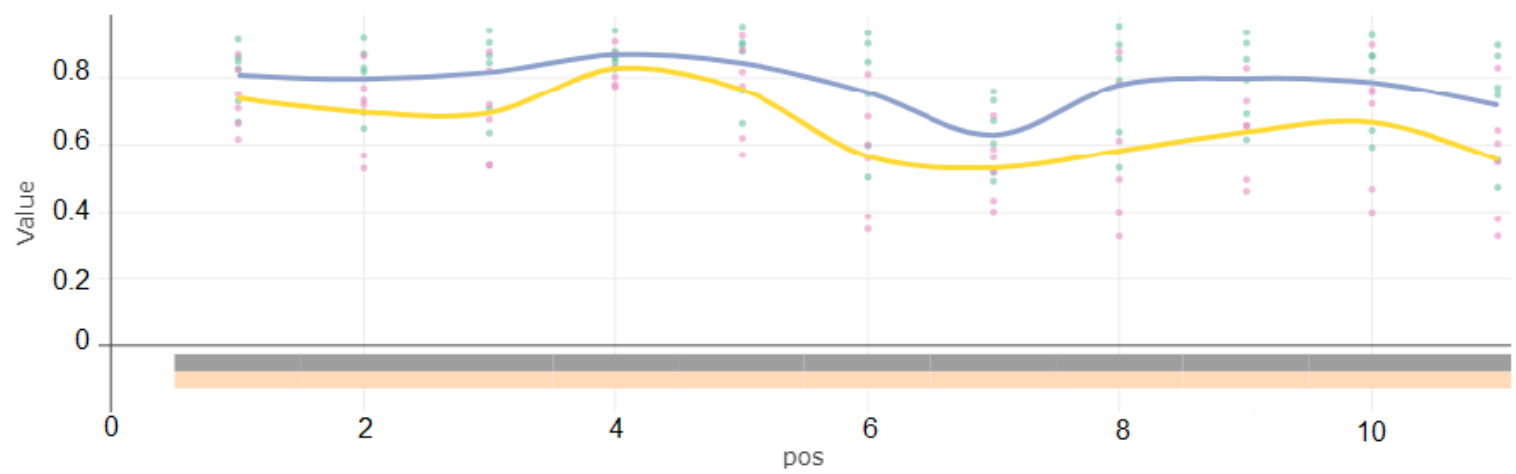

HOXA5

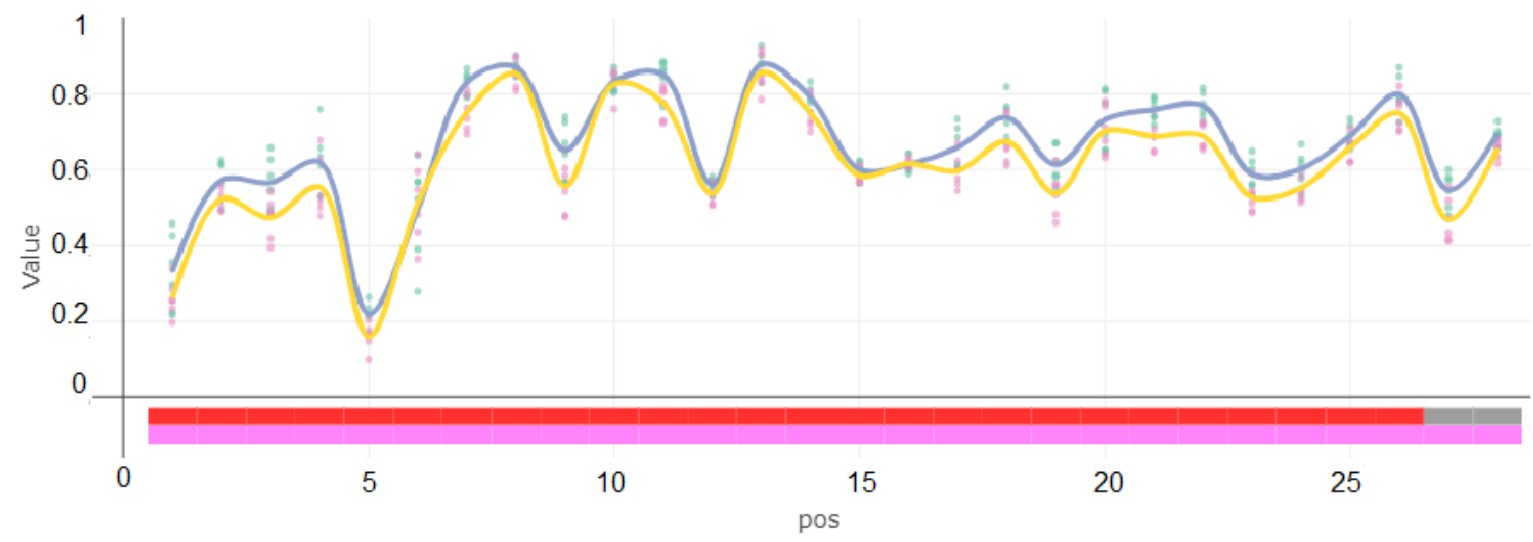

Figure 4. Cont. 


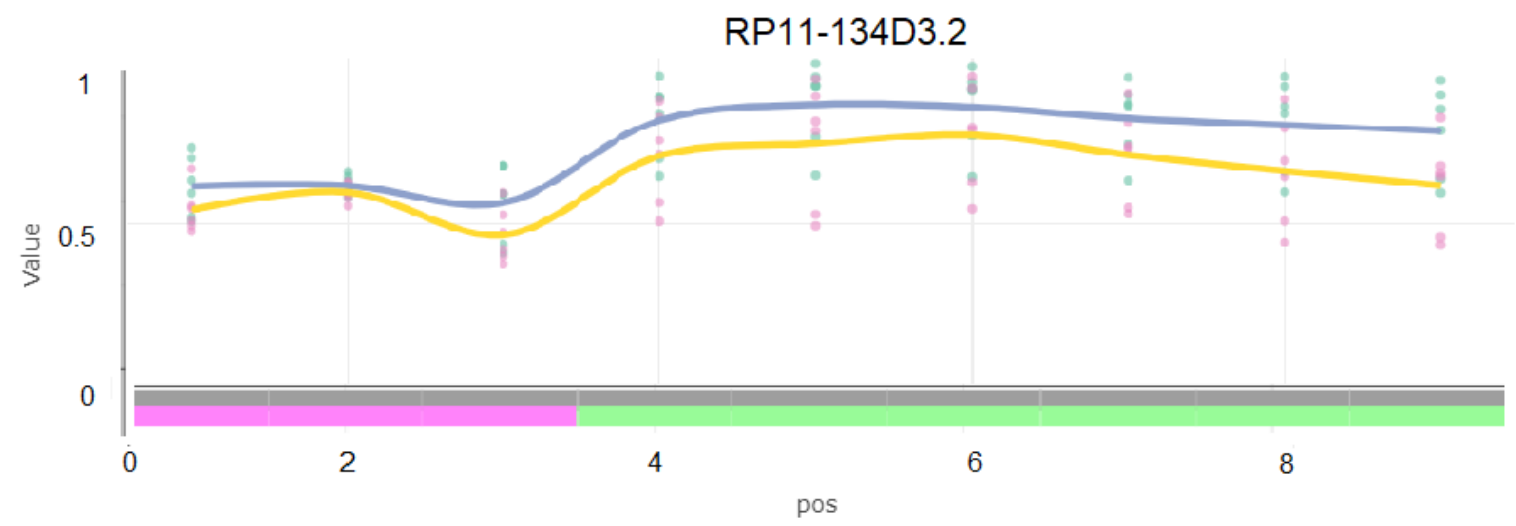

RPL28

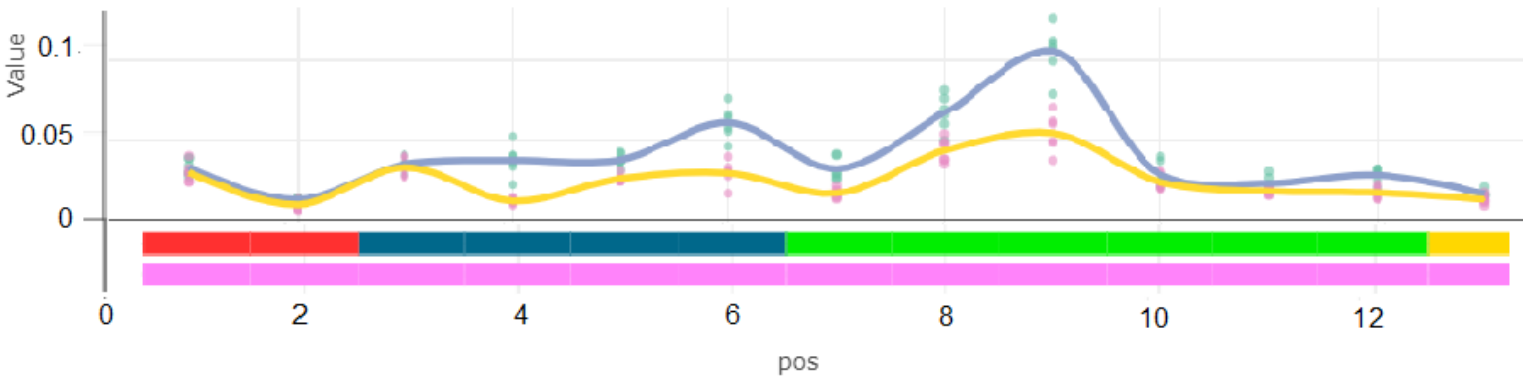

$\begin{array}{lll}\text { CTR } & \text { 1stExon } & \text { IGR } \\ \text { MIX G1 } & \text { 5'UTR } & \text { opensea } \\ \text { CTR mean } & \text { Body } & \text { shore } \\ \text { MIX G1 mean } & \text { TSS1500 } & \text { TSS200 }\end{array}$

Figure 4. Identified differentially methylated regions (DMRs) upon exposure to Mix G1 1X. The yellow line indicates the mean methylation value upon exposure to Mix G1 1X, while the blue line indicates the mean methylation value upon exposure to control. DMR analysis was conducted using the Bumphunter method embedded in the ChAMP analysis package. The plots show beta methylation values ( $Y$ axis) of each consecutive $C$ pG site ( $X$ axis) within each DMR region (not their real genomic location).

Thus, exposure of hMSCs to $1 \mathrm{X}$ and 1000X Mix G1 induced DNA methylation changes in regions linked to genes that play a role in adipogenesis and metabolic functions.

\subsection{Mix G1-Induced DMRs Are Enriched at Genes Linked to Metabolism Related Pathways}

To explore which pathways may be affected by Mix G1 1X induced DMRs, enrichment of gene ontology $(\mathrm{GO})$ categories was performed. To increase the number of included DMR-associated genes, adj. $p$ value $<0.05$ was used. We observed significant enrichment for three major GO categories: biological process (BP) $(n=46)$, cellular component (CC) $(n=14)$, and molecular function (MF) $(n=3)$ (Table S7).

The enrichment results for the BP category demonstrated that Mix G1 1X altered methylation of genes whose products are mainly involved in metabolic processes in the cell on the level of nucleic acids (e.g., nucleic acid metabolic process and mRNA metabolic process), gene expression (e.g., gene expression and regulation of gene expression), and proteins (e.g., protein targeting to ER). Additionally, endocrine system development and cellular macromolecule metabolic processes were enriched (Figure 5). 


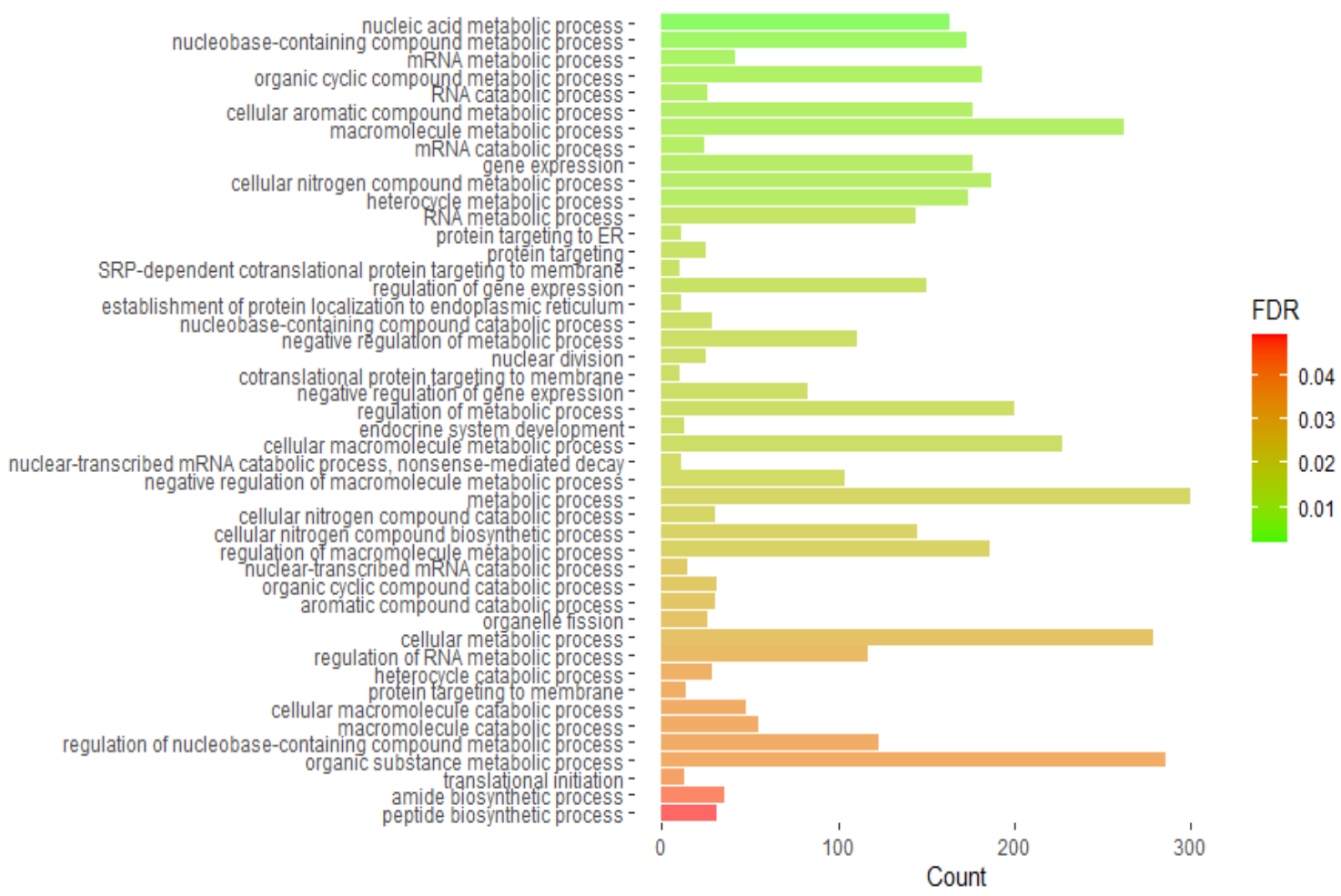

Figure 5. Gene ontology analysis on the list of genes that contain differentially methylated regions showing the biological terms. Count indicates the number of genes enriched in a pathway; FDR indicates False Discovery Rate adjusted $p$ value.

\section{Discussion}

In this study, we tested a mixture of EDCs associated with lower birth weight for cellular and molecular effects in vitro. The mixture, Mix G1, consists of 14 analysed compounds from seven chemical classes. We report, for the first time, that this chemical mixture at levels found in the SELMA mothers can induce adipogenesis and alter DNA methylation in genes important for metabolic functions. While we attempted to relate the ratios of the different components as closely as possible to real-life human exposure, we cannot exclude those different chemical properties affected the actual concentration levels within the cells.

In vitro exposure to Mix G1, already at human relevant concentrations, significantly induced adipogenesis of hMSCs in comparison to control treatment. We observed this when combining hMSCs from two different donors, suggesting that this is not an individualspecific effect. Our results are in accordance with a study by Mentor et al. (2020) [45] that reported significant lipid accumulation in zebrafish upon developmental exposure to a similar EDC mixture. In addition, several other studies have shown promotion of adipogenesis upon exposure to single EDCs included in Mix G1. For example, $1 \mu \mathrm{M}$ of DDE increased adipogenesis in adipose derived MSC and 3T3-L1 adipocytes [72,73], as did $1 \mu \mathrm{M}$ of MEHP in bone marrow stromal cells, and $10 \mu \mathrm{M}$ in primary mouse bone marrow culture and 3T3-L1 adipocytes [74-76]. Several fold higher concentrations of MBzP $(100 \mu \mathrm{M})$ and $\mathrm{MINCH}(50 \mu \mathrm{M})[77,78]$ have promoted adipogenesis in rat primary stromal vascular fraction of adipose tissue and in 3T3-L1 cells, where a similar result was observed upon exposure to PFOA $(40 \mu \mathrm{M})$, PFHxS $(80 \mu \mathrm{M})$, and PFOS $(200 \mu \mathrm{M})[79,80]$.

Contradicting results have been reported for exposure to triclosan with anti-adipogenic effects on hMSCs at 0.156 to $2.5 \mu \mathrm{M}$ and in 3T3-L1 adipocytes at $50 \mu \mathrm{M}$ [81,82], while an in vivo high fat diet with $0.35 \mathrm{mM}$ of triclosan resulted in mice with larger abdominal white adipose tissue [83]. It is evident that most previous studies on single chemicals found in Mix G1 have observed effects at $\mu \mathrm{M}$ concentrations, while Mix G1 showed effects already 
at $100 \mathrm{nM}$, and thus the concentrations of the individual compounds were several folds lower, indicating that the mixture has more potent effects than the single chemicals.

During adipogenesis, bone-marrow derived MSCs develop into adipocytes, and this process is regulated by epigenetic processes, such as changes in DNA methylation patterns at specific genes $[84,85]$. In this study, we showed that Mix G1 induced significant DNA methylation changes at 713 positions already at a relevant human level (1X). The majority of these DMPs were hypomethylated (63\%) in IGR. While the significance of changes in CpG islands for gene expression are well known, the role of the intergenic DNA methylation is not well understood, yet these regions may contain enhancer regulatory sequences or noncoding transcripts or enhancer RNA $[86,87]$. This finding is in accordance with a study conducted by van den Dungen and colleagues (2017) [88] where hMSCs exposed to $10 \mu \mathrm{M}$ PFOS also resulted in more hypomethylated DMPs in the gene body and IGR, although their results were not significant after FDR correction. Interestingly, despite a several fold lower PFOS concentration in Mix G1 1X (9.7 nM), our study identified many DMPs, again suggesting a higher potency of mixture effects in comparison to single chemical effects. A possible mechanism that could explain enrichment of hypomethylated DMPs by Mix G1 could entail interference with nuclear receptors such as the oestrogen receptor.

Oestrogen receptor beta $(\mathrm{ER} \beta)$ has been shown to regulate DNA methylation patterns at specific sites, whereby ER $\beta$ deficiency also showed more hypo- than hypermethylated positions [89]. As an underlying mechanism, Liu and colleagues (2016) [89] proposed recruitment of thymine DNA glycosylase (TDG), an enzyme involved in DNA demethylation [90], to regulatory regions of ER $\beta$ target genes. As TDG has been shown to interact with a number of nuclear receptors [91], this could apply to other receptors affected by Mix G1 compounds as well.

We also observed that Mix G1 10X induced a noticeably different effect than Mix G1 $1 \mathrm{X}$ and 1000X, indicating a possible non-monotonic response. As a result of structural similarities of the EDCs to endogenous hormones, they are well known to be able to induce a response at low doses, as well as exhibit non-monotonic dose-response curves [92,93]. However, no non-monotonic response was observed for the 8 commonly shared DMPs among the treatments, nor in the lipid droplet accumulation assay. Thus, we cannot draw a definite conclusion on whether or not Mix G1 produced non-monotonic effects on the DNA-methylome in hMSCs.

Six hypomethylated DMRs mapped to six genes were identified upon exposure to Mix G1 1X. Remarkably, four of these genes are linked to adipogenesis, adipose tissue function, birthweight, or obesity [67-71,94,95]. The most significant DMRs overlap with the promoter region of the PM20D1 (peptidase M20 domain containing 1) gene. This gene encodes a biosynthetic enzyme that mediates UCP1-independent uncoupling of mitochondrial respiration, driving thermogenesis of brown and beige fat.

PM20D1 is positively regulated in adipocytes by the master regulator of adipogenesis, peroxisome proliferator activated receptor- $\gamma$ nuclear receptor (PPAR $\gamma$ ) $[69,96]$. Recent studies have also shown that methylation of the promoter region of PM20D1 is inversely correlated with its expression in human frontal cortex brain samples [97-99], suggesting that changes in DNA methylation at this region can lead to functional alterations in gene expression.

Furthermore, our analysis identified hypomethylation in a DMR that overlapped with promoter regions of HOXA11 and its anti-sense non-coding RNA HOXA11-AS, as well as a DMR in the HOXA5 gene. These genes have been shown to have an inverse correlation between their promoter methylation and expression, and they have well-established roles in embryonic development in general, and MSC differentiation in particular [68,100-102]. For example, knockdown of HOXA11-AS1 in human adipose-derived stem cells inhibited adipogenesis, and high expression was found in obese patients in comparison to the controls, while low RNA expression was found to be associated with lower birth weight and lower gestational age in humans $[67,103]$. Similarly, a positive correlation between HOXA5 expression and adipogenesis was shown in primary mouse adipocytes, but, con- 
trastingly, low expression was found in adipose tissue of obese mice in comparison to the controls [68,101].

We identified two other DMRs in genes RPL28 and PANCR that have not previously been associated with adipogenesis or lower birth weight before but have appeared in several obesity or metabolism related studies. RPL28 is a gene coding for 605 ribosomal protein L28, and its promoter region, $234 \mathrm{bp}$ away from the DMR we have identified, has been shown to be significantly hypomethylated in obese individuals' blood samples [104]. Furthermore, its expression in subcutaneous white adipose tissue has been negatively associated with BMI in overweight human subjects [71]. While PANCR, an intergenic long noncoding RNA, positively regulates expression of adjacent the PITX2 gene during cardiomyocyte differentiation [94]. Additionally, PITX2 is also important for the development of myocardial components implicated in the pathogenesis of atrial fibrillation, for which low birth weight infants have increased risk of developing later in life [105-107].

Finally, results from the gene ontology analysis were almost exclusively related to molecular and cellular metabolism (Figure 5). Additionally, pathways implicated in processes on organismal level such as endocrine system development and regulation of metabolic processes were enriched. Examples of the identified pathways on the cellular level are establishment of protein localization to endoplasmic reticulum (ER) and protein targeting to ER.

Since stress in ER has been previously linked to adipogenesis and obesity [108], altered DNA methylation in genes involved in the process of transferring proteins to the ER could potentially play a role in adipogenesis.

This study has some limitations. Firstly, we used primary hMSCs from two donors, which limits donor-specific responses to a certain extent. For even more generalisable effects, it would have been beneficial to include hMSCs from additional donors. Furthermore, while differentiation of hMSCs reflects an essential part of gestational development of adipose tissue, it is not by any means exhaustive for studying effects of Mix G1 on metabolic programming. Additionally, we have not quantified the intracellular concentration of Mix G1; thus, the levels and ratios within the cells might deviate from the calculated ones. Also, we did not include Mix G1 100X in the Illumina EPIC DNA methylation analysis, due to limited resources. An additional concentration would have helped to better understand dose-responses of the DNA methylation changes. Lastly, due to limited material, we did not address if the observed DNA methylation changes are correlated with alterations in expression of the respective genes. While this would have added information on the functional implications of our findings, it is of note that epigenetic changes do not necessarily translate directly into transcriptional alterations, but might instead affect, e.g., inducibility of the gene by a later stimulus [109].

\section{Materials and Methods}

\subsection{Identification and Preparation of Mix G1}

The chemical mixture (Mix G1) used experimentally in this study was designed within the EU project EDC-MixRisk (http:/ / edcmixrisk.ki.se/, accessed on 19 February 2022). Levels of 54 compounds were measured in blood and urine of $>2300$ pregnant women in median gestational week 10 included in the Swedish Environmental Longitudinal, Mother and Child, Asthma and allergy (SELMA) study [110]. Forty-one compounds (corresponding to 26 parent compounds), out of the 54 measured, showed levels above the limit of quantification in more than half of the women, and were therefore included in the statistical analyses. The mixture identification includes three steps, also described in Bornehag et al. (2019) and Tables S1 and S2 [44] and in the supplementary material. Firstly, we identified chemicals of concern measured in urine and serum of the SELMA mothers that were associated with a lower birth weight in their children. Such chemicals of concern were selected using weighted quantile sum regression, which is a strategy for estimating empirical weights for a weighted sum of quantiled concentrations (e.g., quartile or decile scores) most associated with the health outcome [111]. The results of this analysis 
are shown in Tables S1 and S2. Secondly, we estimated the serum levels of the chemicals of concern. Urine compounds were converted into serum concentrations through estimation of daily intake [112,113] and chemicals measured in serum were used as such, as described in Bornehag et al. (2019). Thirdly, the mixing proportions of the chemicals of concern were established using serum mean levels from the SELMA mothers. These estimations followed a simplified equation of a one-compartment toxicokinetic model [113]. This procedure resulted in fourteen chemicals of concern that were included in Mix G1.

The components of Mix G1 and their individual concentrations are listed in Table 1. One molar (1 M) solution in DMSO (Sigma-Aldrich, Saint Louis, MO, USA) was prepared. In the experimental systems, this mixture was tested using concentrations corresponding to human exposure, where $1 \mathrm{X}$ denotes the serum mean of exposure levels in SELMA pregnant women.

\subsection{Cell Culture}

Bone marrow-derived hMSCs from 2 donors (one male and one female) were kindly provided by Dr. Katarina Leblanc (Karolinska Institutet, Stockholm, Sweden). Two donors were used to decrease the risk of donor-specific findings, and the results from the two donors were not separated in the statistical analyses. The cells were cultured in growth media consisting of DMEM (Gibco, Waltham, MA, USA) supplemented with 10\% Fetal Bovine Serum (FBS; Gibco, Waltham, MA, USA), 1\% penicillin-streptomycin (Gibco, Waltham, MA, USA), and $2 \%$ L-glutamine (Gibco, Waltham, MA, USA) at $37^{\circ} \mathrm{C}$ in an incubator with $5 \%$ $(v / v) \mathrm{CO}_{2}$.

The hMSCs were seeded in black-walled 96 well plates with $\mu$ CLEAR bottom (Greiner Bio One, Kremsmünster, Austria) or 6 well-plates (VWR $\rightarrow 734-2323)$. Growth media was replaced by treatment media (TM) consisting of DMEM supplemented with $10 \%$ charcoal stripped FBS (DCC, Gibco, Waltham, MA, USA), 1\% penicillin-streptomycin (Gibco, Waltham, MA, USA), and 2\% L-glutamine (Gibco, Waltham, MA, USA) two-three days before treatment start (day 0). On day 0, the treatments started and continued for 21 days. The Mix G1 exposure media (EM) consisted of TM supplemented with Mix G1 in DMSO at $10 \mathrm{nM}(0.1 \mathrm{X}), 100 \mathrm{nM}(1 \mathrm{X}), 1 \mu \mathrm{M}$ (10X), $10 \mu \mathrm{M}$ (100X), and $100 \mu \mathrm{M}$ (1000X). Control medium (CM) contained TM supplemented with DMSO in a ratio of 1:1000. As positive control, adipogenic induction media (AIM), consisting of TM supplemented with $1 \mu \mathrm{g} / \mathrm{mL}$ insulin (Sigma-Aldrich, Saint Louis, MO, USA), $0.25 \mathrm{uM}$ dexamethasone (Sigma-Aldrich, Saint Louis, MO, USA) and 0.5 mM 3-isobutyl-1-methylxanthine (IBMX, Sigma-Aldrich, Saint Louis, MO, USA), was used. EM/CM/AIM were changed twice a week.

AIM induced adipogenesis (measured as lipid droplet accumulation) in all experiments for both donors.

\subsection{Lipid Droplet Accumulation}

Differentiation of hMSCs into adipocytes was quantified by fluorescent microscopy, as previously described [114]. Briefly, media from the cultured cells in 96 well plates was replaced by $100 \mu \mathrm{L}$ media containing $10 \mu \mathrm{g} / \mathrm{mL}$ BODIPY 493/503 (Gibco ${ }^{\circledR}$, Waltham, MA, USA) and $2 \mu \mathrm{g} / \mathrm{mL}$ of Hoechst 33,342 (Gibco ${ }^{\circledR}$, Waltham, MA, USA) and incubated for $1 \mathrm{~h}$ at $37{ }^{\circ} \mathrm{C}, 5 \% \mathrm{CO}_{2}$. The cells were then washed three times with DPBS with $\mathrm{Ca}$ and $\mathrm{Mg}$ (Gibco, Waltham, MA, USA), after which images were immediately taken in FITC and DAPI channels at $10 \mathrm{X}$ magnification, at 16 sites per well, using the Image Xpress Micro HighContent Analysis System. Images were further analyzed with the MetaXpress High-Content Image Acquisition and Analysis software (Molecular Devices, Sunnyvale, CA, USA). Using the Transfluor HT analysis module, lipid droplets were quantified by measuring the integrated granule intensity, and this value was normalized to nuclei count. For each treatment condition, the lipid accumulation per cell is presented as a ratio compared to the lipid accumulation per cell of the DMSO control on the same plate. 


\subsection{DNA Extraction and Genome-Wide DNA Methylation Analysis}

The DNA was extracted from hMSCs cultured in 6-well plates using AllPrep DNA/RNA micro kit (Qiagen, Hilden, Germany), according to the manufacturer's protocol. Briefly, the cultured cells were lysed with a lysis buffer from BioRad (Aurum Total RNA Lysis Solution), lysate was then frozen in $-80^{\circ} \mathrm{C}$. When thawed, $250 \mu \mathrm{L}$ of RLT buffer was added and the lysate was transferred to a spin column, washed and centrifuged several times according to protocol. DNA was eluted with EB buffer. The Illumina EPIC Array analysis was conducted by the core facility for Bioinformatics and Expression Analysis (BEA) (Karolinska Institutet, Stockholm, Sweden).

The data was normalized and pre-processed by BEA using Chip Analysis Methylation Pipeline (ChAMP) where quality control and batch correction for slide and array were performed. The distribution of DMPs were determined against the base genome annotation for Illumina's EPIC methylation array (Homo sapiens genome assembly GRCh37 (hg19)). The degree of methylation at a CpG site (beta-value $(\beta)$ ) was calculated using Formula (1), where the ratio of methylated fluorescent probe intensity against a total probe intensity signal was calculated with a constant offset of $100[115,116]$. The beta value is always between 0 and 1, where 1 indicates that a CpG site is 100\% methylated and 0 indicates $0 \%$ methylation. The Delta Beta value is defined as the difference between the average beta values of the treatment (Mix G1) and the control samples (Formula (2)). Therefore, a negative Delta Beta value refers to the treatment sample being less methylated than control, hypomethylated, and positive Delta Beta value refers to the treatment sample being more methylated than control, hypermethylated.

$\beta=$ Methylated probe intensity $\div($ Unmethylated probe intensity + Methylated probe intensity +100$)$

Formula (1). Calculation of the beta-value ( $\beta$ ) in the Illumina EPIC Array.

$$
\begin{aligned}
& \text { Deltabeta } \\
& \text { = Average beta value of Mix G1 samples } \\
& \text { - Average beta value control samples }
\end{aligned}
$$

Formula (2). Calculation of the Delta Beta value.

The $p$-value was adjusted for multiple testing using false discovery rate (FDR) and differentially methylated CpG positions (DMPs) were identified based on differences in DNA methylation means between the treatment groups (Mix G1 1X, 10X and 1000X) and control (DMSO) group (absolute value of $\Delta \beta \geq 0.1$ and FDR $<0.05$ ).

To investigate how the different samples clustered, a principle component analysis (PCA) was conducted using the singular value decomposition function ( $\backslash$ textit\{prcomp\}) in R, version 4.0.5; the distribution of DMPs and the volcano plots were also conducted in R, version 4.0.5, using the base genome annotation for Illumina's EPIC methylation array (Homo sapiens genome assembly GRCh37 (hg19)) and ggplot2 [117] package, respectively.

To investigate methylation changes at a region level, the Bumphunter tool was employed where an algorithm uses "peak detection" method for DMRs identification [117]. In short, regression coefficients of adjacent CpGs in a region are smoothed and plotted in a curve. Potential "peaks" or DMRs are then identified as regions where the collection of these coefficients are higher than expected by chance [118-120]. The Bumphunter (champ.DMR) function from the ChAMP package was used for DMR analysis with its default setting for DMR composition of seven or more successive DMPs within a 300-base pair genomic region. The DMRs with Family Wise Error Rate $<0.2$ were considered differentially methylated. Genes were extracted from the DMR analysis with adjusted $p$ value cut off by 0.05 and used in a testing for enrichment of gene ontology (GO) categories from the GO.db annotation package, using functions called "GOmeth" and "champ.GSEA" with default settings. Both DMR and GO analysis were conducted on combined data from both donors, and to account for sex bias, sex chromosomes were excluded. 


\section{Conclusions}

In conclusion, our study showed that a human relevant EDC mixture of 14 analysed compounds induced lipid droplet accumulation of hMSCs. Additionally, we found that exposure to the mixture leads to dysregulated DNA methylation patterns of genes previously associated with lower birth weight, obesity, as well as development and function of adipose tissue. Thus, this study suggests that a mixture corresponding to human real-life exposures, both in terms of proportions and concentrations, can change the metabolic set-point during development, which may underlie the epidemiological association between chemical mixture and lower birth weight. This, therefore, emphasizes the need for taking chemical mixture exposure into account, both in research and for regulatory risk and hazard assessment.

Supplementary Materials: The following supporting information can be downloaded at: https: //www.mdpi.com/article/10.3390/ijms23042320/s1.

Author Contributions: Conceptualization, J.R., E.E. and C.-G.B.; methodology, G.B., J.R., E.E., C.G. and P.L.; formal analysis, P.L., C.G. and E.E.; investigation, G.B., E.E. and P.L.; resources, C.L.; writing - original draft preparation, J.R., E.E. and P.L.; writing-review and editing, C.-G.B., C.L. and C.G.; visualization, E.E., P.L. and C.-G.B.; supervision, J.R., C.-G.B. and E.E.; funding acquisition, J.R. and C.-G.B. All authors have read and agreed to the published version of the manuscript.

Funding: This research was funded by the "Swedish Research Council for Sustainable Development (FORMAS), grant number 2018-02279" and "European Union Horizon 2020 Research and Innovation Programme, grant number 634880".

Institutional Review Board Statement: The study was conducted in accordance with the Declaration of Helsinki, and approved by the regional ethical committee, Uppsala, Sweden (Dnr: 2007/062, 2007-05-02 and Dnr 2015/177).

Informed Consent Statement: Written informed consent was obtained from all subjects involved in the study.

Data Availability Statement: The data discussed in this publication have been deposited in NCBI's Gene Expression Omnibus and are accessible through GEO Series accession number GSE196046.

Acknowledgments: We acknowledge the core facility for Bioinformatics and Expression Analysis (BEA) (Karolinska Institutet) for Illumina EPIC Array sequencing and analysis. We would also like to thank Vesna Munic Kos (Karolinska Institutet) for her help with optimisation of the human mesenchymal stem cell culturing protocol and Ximiao Yu for DNA methylation laboratory work.

Conflicts of Interest: The authors declare no conflict of interest. The funders had no role in the design of the study; in the collection, analyses, or interpretation of data; in the writing of the manuscript, or in the decision to publish the results.

\section{References}

1. Diamanti-Kandarakis, E.; Bourguignon, J.-P.; Giudice, L.C.; Hauser, R.; Prins, G.S.; Soto, A.M.; Zoeller, R.T.; Gore, A.C. EndocrineDisrupting Chemicals: An Endocrine Society Scientific Statement. Endocr. Rev. 2009, 30, 293-342. [CrossRef] [PubMed]

2. Yilmaz, B.; Terekeci, H.; Sandal, S.; Kelestimur, F. Endocrine Disrupting Chemicals: Exposure, effects on human health, mechanism of action, models for testing and strategies for prevention. Rev. Endocr. Metab. Disord. 2020, 21, 127-147. [CrossRef] [PubMed]

3. Woodruff, T.J.; Zota, A.R.; Schwartz, J.M. Environmental Chemicals in Pregnant Women in the United States: NHANES 2003-2004. Environ. Health Perspect. 2011, 119, 878-885. [CrossRef] [PubMed]

4. Kumar, M.; Sarma, D.K.; Shubham, S.; Kumawat, M.; Verma, V.; Prakash, A.; Tiwari, R. Environmental Endocrine-Disrupting Chemical Exposure: Role in Non-Communicable Diseases. Front. Public Health 2020, 8, 549. [CrossRef] [PubMed]

5. Engdahl, E.; Rüegg, J. Prenatal Exposure to Endocrine Di.isrupting Chemicals and Their Effect on Health Later in Life. In Beyond Our Genes: Pathophysiology of Gene and Environment Interaction and Epigenetic Inheritance; Teperino, R., Ed.; Springer International Publishing: Cham, Switzerland, 2020; pp. 53-77, ISBN 978-3-030-35213-4.

6. Gancz, D.; Gilboa, L. Hormonal Control of Stem Cell Systems. Annu. Rev. Cell Dev. Biol. 2013, 29, 137-162. [CrossRef] [PubMed]

7. Kopchick, J.J.; Berryman, D.E.; Puri, V.; Lee, K.Y.; Jorgensen, J.O.L. The effects of growth hormone on adipose tissue: Old observations, new mechanisms. Nat. Rev. Endocrinol. 2020, 16, 135-146. [CrossRef] [PubMed]

8. de Sá, P.M.; Richard, A.J.; Hang, H.; Stephens, J.M. Transcriptional Regulation of Adipogenesis. In Comprehensive Physiology; John Wiley \& Sons, Ltd.: Hoboken, NJ, USA, 2017; pp. 635-674, ISBN 978-0-470-65071-4. 
9. Braun, J.M. Early-life exposure to EDCs: Role in childhood obesity and neurodevelopment. Nat. Rev. Endocrinol. 2017, 13, 161-173. [CrossRef] [PubMed]

10. Cohen, I.C.; Cohenour, E.R.; Harnett, K.G.; Schuh, S.M. BPA, BPAF and TMBPF Alter Adipogenesis and Fat Accumulation in Human Mesenchymal Stem Cells, with Implications for Obesity. Int. J. Mol. Sci 2021, 22, 5363. [CrossRef]

11. Hack, M.; Klein, N.K.; Taylor, H.G. Long-term developmental outcomes of low birth weight infants. Future Child. 1995, 5, 176-196. [CrossRef]

12. McGuire, S.F. Understanding the Implications of Birth Weight. Nurs. Women's Health 2017, 21, 45-49. [CrossRef]

13. Gluckman, P.D.; Hanson, M.A.; Cooper, C.; Thornburg, K.L. Effect of in utero and early-life conditions on adult health and disease. N. Engl. J. Med. 2008, 359, 61-73. [CrossRef]

14. Barker, D.J.P.; Osmond, C. Infant mortality, childhood nutrition, and ischaemic heart disease in England and Wales. Lancet 1986, 327, 1077-1081. [CrossRef]

15. Roberts, G.; Cheong, J.L.Y. Long-term growth and general health for the tiniest or most immature infants. Semin. Fetal Neonatal Med. 2014, 19, 118-124. [CrossRef] [PubMed]

16. Barker, D.J.P. The origins of the developmental origins theory. J. Intern. Med. 2007, 261, 412-417. [CrossRef] [PubMed]

17. Kopec, G.; Shekhawat, P.S.; Mhanna, M.J. Prevalence of diabetes and obesity in association with prematurity and growth restriction. DMSO 2017, 10, 285-295. [CrossRef]

18. Wikström, S.; Lin, P.-I.; Lindh, C.H.; Shu, H.; Bornehag, C.-G. Maternal serum levels of perfluoroalkyl substances in early pregnancy and offspring birth weight. Pediatr. Res. 2020, 87, 1093-1099. [CrossRef]

19. Marks, K.J.; Cutler, A.J.; Jeddy, Z.; Northstone, K.; Kato, K.; Hartman, T.J. Maternal serum concentrations of perfluoroalkyl substances and birth size in British boys. Int. J. Hyg. Environ. Health 2019, 222, 889-895. [CrossRef]

20. Gyllenhammar, I.; Diderholm, B.; Gustafsson, J.; Berger, U.; Ridefelt, P.; Benskin, J.P.; Lignell, S.; Lampa, E.; Glynn, A. Perfluoroalkyl acid levels in first-time mothers in relation to offspring weight gain and growth. Environ. Int. 2018, 111, 191-199. [CrossRef]

21. Lenters, V.; Portengen, L.; Rignell-Hydbom, A.; Jönsson, B.A.G.; Lindh, C.H.; Piersma, A.H.; Toft, G.; Bonde, J.P.; Heederik, D.; Rylander, L.; et al. Prenatal Phthalate, Perfluoroalkyl Acid, and Organochlorine Exposures and Term Birth Weight in Three Birth Cohorts: Multi-Pollutant Models Based on Elastic Net Regression. Environ. Health Perspect. 2016, 124, 365-372. [CrossRef]

22. Birks, L.; Casas, M.; Garcia, A.M.; Alexander, J.; Barros, H.; Bergström, A.; Bonde, J.P.; Burdorf, A.; Costet, N.; Danileviciute, A.; et al. Occupational Exposure to Endocrine-Disrupting Chemicals and Birth Weight and Length of Gestation: A European Meta-Analysis. Environ. Health Perspect. 2016, 124, 1785-1793. [CrossRef]

23. Ghassabian, A.; Vandenberg, L.; Kannan, K.; Trasande, L. Endocrine-Disrupting Chemicals and Child Health. Annu. Rev. Pharmacol. Toxicol. 2021, 22, 573-594. [CrossRef] [PubMed]

24. Starling, A.P.; Adgate, J.L.; Hamman, R.F.; Kechris, K.; Calafat, A.M.; Dabelea, D. Prenatal exposure to per- and polyfluoroalkyl substances and infant growth and adiposity: The Healthy Start Study. Environ. Int. 2019, 131, 104983. [CrossRef] [PubMed]

25. Halldorsson, T.I.; Rytter, D.; Haug, L.S.; Bech, B.H.; Danielsen, I.; Becher, G.; Henriksen, T.B.; Olsen, S.F. Prenatal Exposure to Perfluorooctanoate and Risk of Overweight at 20 Years of Age: A Prospective Cohort Study. Environ. Health Perspect. 2012, 120, 668-673. [CrossRef] [PubMed]

26. Braun, J.M.; Chen, A.; Romano, M.E.; Calafat, A.M.; Webster, G.M.; Yolton, K.; Lanphear, B.P. Prenatal Perfluoroalkyl Substance Exposure and Child Adiposity at 8 Years of Age: The HOME Study. Obesity 2016, 24, 231-237. [CrossRef]

27. Mora, A.M.; Oken, E.; Rifas-Shiman, S.L.; Webster, T.F.; Gillman, M.W.; Calafat, A.M.; Ye, X.; Sagiv, S.K. Prenatal Exposure to Perfluoroalkyl Substances and Adiposity in Early and Mid-Childhood. Environ. Health Perspect. 2017, 125, 467-473. [CrossRef]

28. Howard, S.G. Developmental Exposure to Endocrine Disrupting Chemicals and Type 1 Diabetes Mellitus. Front. Endocrinol. 2018, 9, 513. [CrossRef]

29. Blake, B.E.; Fenton, S.E. Early life exposure to per- and polyfluoroalkyl substances (PFAS) and latent health outcomes: A review including the placenta as a target tissue and possible driver of peri- and postnatal effects. Toxicology 2020, 443, 152565. [CrossRef]

30. Heindel, J.J.; Blumberg, B.; Cave, M.; Machtinger, R.; Mantovani, A.; Mendez, M.A.; Nadal, A.; Palanza, P.; Panzica, G.; Sargis, R.; et al. Metabolism Disrupting Chemicals and Metabolic Disorders. Reprod. Toxicol. 2017, 68, 3-33. [CrossRef]

31. Papalou, O.; Kandaraki, E.A.; Papadakis, G.; Diamanti-Kandarakis, E. Endocrine Disrupting Chemicals: An Occult Mediator of Metabolic Disease. Front. Endocrinol. 2019, 10, 112. [CrossRef]

32. Wu, H.; Sun, Y.E. Epigenetic Regulation of Stem Cell Differentiation. Pediatr. Res. 2006, 59, 21-25. [CrossRef]

33. Atlasi, Y.; Stunnenberg, H.G. The interplay of epigenetic.c marks during stem cell differentiation and development. Nat. Rev. Genet. 2017, 18, 643-658. [CrossRef] [PubMed]

34. Kiefer, J.C. Epigenetics in development. Dev. Dyn. 2007, 236, 1144-1156. [CrossRef] [PubMed]

35. Nicoglou, A.; Merlin, F. Epigenetics: A way to bridge the gap between biological fields. Stud. Hist. Philos. Biol. Biomed. Sci. 2017, 66, 73-82. [CrossRef] [PubMed]

36. Jacobs, M.N.; Marczylo, E.L.; Guerrero-Bosagna, C.; Rüegg, J. Marked for Life: Epigenetic Effects of Endocrine Disrupting Chemicals. Annu. Rev. Environ. Resour. 2017, 42, 105-160. [CrossRef]

37. Zhu, Z.; Cao, F.; Li, X. Epigenetic Programming and Fetal Metabolic Programming. Front. Endocrinol. 2019, 10, 764. [CrossRef]

38. Moore, L.D.; Le, T.; Fan, G. DNA Methylation and Its Basic Function. Neuropsychopharmacology 2013, 38, 23-38. [CrossRef] 
39. Vilahur, N.; Bustamante, M.; Morales, E.; Motta, V.; Fernandez, M.F.; Salas, L.A.; Escaramis, G.; Ballester, F.; Murcia, M.; Tardon, A.; et al. Prenatal exposure to mixtures of xenoestrogens and genome-wide DNA methylation in human placenta. Epigenomics 2016, 8, 43-54. [CrossRef]

40. Wadhwa, P.D.; Buss, C.; Entringer, S.; Swanson, J.M. Developmental Origins of Health and Disease: Brief History of the Approach and Current Focus on Epigenetic Mechanisms. Semin. Reprod. Med. 2009, 27, 358-368. [CrossRef]

41. Kortenkamp, A. Low dose mixture effects of endocrine disrupters and their implications for regulatory thresholds in chemical risk assessment. Curr. Opin. Pharmacol. 2014, 19, 105-111. [CrossRef]

42. Hernández, A.F.; Tsatsakis, A.M. Human exposure to chemical mixtures: Challenges for the integration of toxicology with epidemiology data in risk assessment. Food Chem. Toxicol. 2017, 103, 188-193. [CrossRef]

43. Ribeiro, E.; Ladeira, C.; Viegas, S. EDCs Mixtures: A Stealthy Hazard for Human Health? Toxics 2017, 5, 5. [CrossRef] [PubMed]

44. Bornehag, C.-G.; Kitraki, E.; Stamatakis, A.; Panagiotidou, E.; Rudén, C.; Shu, H.; Lindh, C.; Ruegg, J.; Gennings, C. A Novel Approach to Chemical Mixture Risk Assessment_Linking Data from Population-Based Epidemiology and Experimental Animal Tests. Risk Anal. 2019, 39, 2259-2271. [CrossRef] [PubMed]

45. Mentor, A.; Brunström, B.; Mattsson, A.; Jönsson, M. Developmental exposure to a human relevant mixture of endocrine disruptors alters metabolism and adipogenesis in zebrafish (Danio rerio). Chemosphere 2020, 238, 124584. [CrossRef] [PubMed]

46. Repouskou, A.; Panagiotidou, E.; Panagopoulou, L.; Bisting, P.L.; Tuck, A.R.; Sjödin, M.O.D.; Lindberg, J.; Bozas, E.; Rüegg, J.; Gennings, C.; et al. Gestational exposure to an epidemiologically defined mixture of phthalates leads to gonadal dysfunction in mouse offspring of both sexes. Sci. Rep. 2019, 9, 6424. [CrossRef]

47. Caporale, N.; Leemans, M.; Birgersson, L.; Germain, P.-L.; Cheroni, C.; Borbély, G.; Engdahl, E.; Lindh, C.; Bressan, R.B.; Cavallo, F.; et al. From cohorts to molecules: Adverse impacts of endocrine disrupting mixtures. Science 2022, 375, 6852. [CrossRef]

48. Poissonnet, C.M.; Burdi, A.R.; Bookstein, F.L. Growth and development of human adipose tissue during early gestation. Early Hum. Dev. 1983, 8, 1-11. [CrossRef]

49. Orsso, C.E.; Colin-Ramirez, E.; Field, C.J.; Madsen, K.L.; Prado, C.M.; Haqq, A.M. Adipose Tissue Development and Expansion from the Womb to Adolescence: An Overview. Nutrients 2020, 12, 2735. [CrossRef]

50. Chen, Y.-S.; Wu, R.; Yang, X.; Kou, S.; MacDougald, O.A.; Yu, L.; Shi, H.; Xue, B. Inhibiting DNA methylation switches adipogenesis to osteoblastogenesis by activating Wnt10a. Sci. Rep. 2016, 6, 25283. [CrossRef]

51. Shamsi, F.; Xue, R.; Huang, T.L.; Lundh, M.; Liu, Y.; Leiria, L.O.; Lynes, M.D.; Kempf, E.; Wang, C.-H.; Sugimoto, S.; et al. FGF6 and FGF9 regulate UCP1 expression independent of brown adipogenesis. Nat. Commun. 2020, 11, 1421. [CrossRef]

52. Nozato, Y.; Takami, Y.; Yamamoto, K.; Nagasawa, M.; Nozato, S.; Imaizumi, Y.; Takeshita, H.; Wang, C.; Ito, Y.; Takeda, S.; et al. Novel properties of myoferlin in glucose metabolism via pathways involving modulation of adipose functions. FASEB J. 2020, 34, 2792-2811. [CrossRef]

53. Chen, N.; Wang, J. Wnt/ $\beta$-Catenin Signaling and Obesity. Front. Physiol. 2018, 9, 792. [CrossRef] [PubMed]

54. Ellis, J.M.; Bowman, C.E.; Wolfgang, M.J. Metabolic and Tissue-Specific Regulation of Acyl-CoA Metabolism. PLoS ONE 2015, 10, e0116587. [CrossRef] [PubMed]

55. Płatek, T.; Polus, A.; Góralska, J.; Raźny, U.; Gruca, A.; Kieć-Wilk, B.; Zabielski, P.; Kapusta, M.; Słowińska-Solnica, K.; Solnica, B.; et al. DNA methylation microarrays identify epigenetically regulated lipid related genes in obese patients with hypercholesterolemia. Mol. Med. 2020, 26, 93. [CrossRef] [PubMed]

56. Wang, K.; Li, W.-D.; Zhang, C.K.; Wang, Z.; Glessner, J.T.; Grant, S.F.A.; Zhao, H.; Hakonarson, H.; Price, R.A. A Genome-Wide Association Study on Obesity and Obesity-Related Traits. PLoS ONE 2011, 6, e18939. [CrossRef]

57. Alvine, T.; Dhasarathy, A.; Bundy, A.; Bhattacharya, A.; Darland, D.; Hur, J.; Perley, D.; Johnson, L.; Rusten, M.; Roemmich, J.; et al. RBMS1 Methylation and mRNA Expression Are Differentially Regulated in Placenta Tissue from Obese Women (P11-131-19). Curr. Dev. Nutr. 2019, 3, nzz048.P11-131-19. [CrossRef]

58. Bradley, D.; Yin, Z.; Liu, J.Z.; Blaszczak, A.M.; Wong, S.T.; Hsueh, W. Adipocyte EGFL6 Expression from Subcutaneous Adipose Tissue Alters Glucose Homeostasis and Affects Human Obesity. Diabetes 2018, 67, 1751. [CrossRef]

59. Klenke, S.; Tan, S.; Hahn, S.; Mann, K.; Hauner, H.; Manthey, I.; Peters, J.; Siffert, W.; Frey, U.H. A functional GNAQ promoter haplotype is associated with altered Gq expression and with insulin resistance and obesity in women with polycystic ovary syndrome. Pharm. Genom. 2010, 20, 476-484. [CrossRef]

60. Krüger, J.; Brachs, S.; Trappiel, M.; Kintscher, U.; Meyborg, H.; Wellnhofer, E.; Thöne-Reineke, C.; Stawowy, P.; Östman, A.; Birkenfeld, A.L.; et al. Enhanced insulin signaling in den.nsity-enhanced phosphatase-1 (DEP-1) knockout mice. Mol. Metab. 2015, 4, 325-336. [CrossRef]

61. Liu, L.; Chen, L.; Li, Z.; Li, L.; Wang, M.; Qu, J.; Xue, J. Association of genetic variants in TOMM7 gene and gene environment interaction with type 2 diabetes in Chinese Dong population. Zhong Nan Da Xue Xue Bao Yi Xue Ban 2015, 40, 31-38. [CrossRef]

62. Iván, J.; Major, E.; Sipos, A.; Kovács, K.; Horváth, D.; Tamás, I.; Bay, P.; Dombrádi, V.; Lontay, B. The Short-Chain Fatty Acid Propionate Inhibits Adipogenic Differentiation of Human Chorion-Derived Mesenchymal Stem Cells Through the Free Fatty Acid Receptor 2. Stem. Cells Dev. 2017, 26, 1724-1733. [CrossRef]

63. Miki, H.; Yamauchi, T.; Suzuki, R.; Komeda, K.; Tsuchida, A.; Kubota, N.; Terauchi, Y.; Kamon, J.; Kaburagi, Y.; Matsui, J.; et al. Essential Role of Insulin Receptor Substrate 1 (IRS-1) and IRS-2 in Adipocyte Differentiation. Mol. Cell Biol. 2001, 21, 2521-2532. [CrossRef] [PubMed] 
64. Serria, M.S.; Ikeda, H.; Omoteyama, K.; Hirokawa, J.; Nishi, S.; Sakai, M. Regulation and differential expression of the c-maf gene in differentiating cultured cells. Biochem. Biophys. Res. Commun. 2003, 310, 318-326. [CrossRef] [PubMed]

65. Voermans, N.C.; Preisler, N.; Madsen, K.L.; Janssen, M.C.H.; Kusters, B.; Abu Bakar, N.; Conte, F.; Lamberti, V.M.L.; Nusman, F.; van Engelen, B.G.; et al. PGM1 deficiency: Substrate use during exercise and effect of treatment with galactose. Neuromuscul. Disord. 2017, 27, 370-376. [CrossRef] [PubMed]

66. Haller, R.; Heinicke, K.; Newby, M.; Wyrick, P.; Dimitrov, I.; Mancias, P.; Cohen, J. Phosphoglucomutase (PGM 1) Deficiency: A Novel Defect of Muscle Glycogen Degradation and Synthesis (P07.200). Neurology 2012, 78, P07.200. [CrossRef]

67. Nuermaimaiti, N.; Liu, J.; Liang, X.; Jiao, Y.; Zhang, D.; Liu, L.; Meng, X.; Guan, Y. Effect of lncRNA HOXA11-AS1 on adipocyte differentiation in human adipose-derived stem cells. Biochem. Biophys Res. Commun. 2018, 495, 1878-1884. [CrossRef]

68. Cao, W.; Xu, Y.; Luo, D.; Saeed, M.; Sun, C. Hoxa5 Promotes Adipose Differentiation via Increasing DNA Methylation Level and Inhibiting PKA/HSL Signal Pathway in Mice. CPB 2018, 45, 1023-1033. [CrossRef]

69. Benson, K.K.; Hu, W.; Weller, A.H.; Bennett, A.H.; Chen, E.R.; Khetarpal, S.A.; Yoshino, S.; Bone, W.P.; Wang, L.; Rabinowitz, J.D.; et al. Natural human genetic variation determines basal and inducible expression of PM20D1, an obesity-associated gene. Proc. Natl. Acad. Sci. USA 2019, 116, 23232-23242. [CrossRef]

70. Pant, R.; Firmal, P.; Shah, V.K.; Alam, A.; Chattopadhyay, S. Epigenetic Regulation of Adipogenesis in Development of Metabolic Syndrome. Front. Cell Dev. Biol. 2021, 8, 1766. [CrossRef]

71. Henegar, C.; Tordjman, J.; Achard, V.; Lacasa, D.; Cremer, I.; Guerre-Millo, M.; Poitou, C.; Basdevant, A.; Stich, V.; Viguerie, N.; et al. Adipose tissue transcriptomic signature highlights the pathological relevance of extracellular matrix in human obesity. Genome. Biol. 2008, 9, R14. [CrossRef]

72. Kim, J.; Sun, Q.; Yue, Y.; Yoon, K.S.; Whang, K.-Y.; Marshall Clark, J.; Park, Y. 4,4'-Dichlorodiphenyltrichloroethane (DDT) and 4,4'-dichlorodiphenyldichloroethylene (DDE) promote adipogenesis in 3T3-L1 adipocyte cell culture. Pestic. Biochem. Physiol. 2016, 131, 40-45. [CrossRef]

73. Pesta, M.; Cedikova, M.; Dvorak, P.; Dvorakova, J.; Kulda, V.; Srbecka, K.; Muller, L.; Bouchalova, V.; Kralickova, M.; Babuska, V.; et al. Trends in gene expression changes during adipogenesis in human adipose derived mesenchymal stem cells under dichlorodiphenyldichloroethylene exposure. Mol. Cell. Toxicol. 2018, 14, 369-379. [CrossRef]

74. Watt, J.; Schlezinger, J.J. Structurally-diverse, PPAR $\gamma$-activating environmental toxicants induce adipogenesis and suppress osteogenesis in bone marrow mesenchymal stromal cells. Toxicology 2015, 331, 66-77. [CrossRef] [PubMed]

75. Feige, J.N.; Gelman, L.; Rossi, D.; Zoete, V.; Métivier, R.; Tudor, C.; Anghel, S.I.; Grosdidier, A.; Lathion, C.; Engelborghs, Y.; et al The Endocrine Disruptor Monoethyl-hexyl-phthalate Is a Selective Peroxisome Proliferator-activated Receptor $\gamma$ Modulator That Promotes Adipogenesis. J. Biol. Chem. 2007, 282, 19152-19166. [CrossRef] [PubMed]

76. Chiu, C.-Y.; Sun, S.-C.; Chiang, C.-K.; Wang, C.-C.; Chan, D.-C.; Chen, H.-J.; Liu, S.-H.; Yang, R.-S. Plasticizer di(2ethylhexyl)phthalate interferes with osteoblastogenesis and adipogenesis in a mouse model. J. Orthop. Res. 2018, 36, 1124-1134. [CrossRef] [PubMed]

77. Hurst, C.H.; Waxman, D.J. Activation of PPAR $\alpha$ and PPAR $\gamma$ by Environmental Phthalate Monoesters. Toxicol. Sci. 2003, 74, 297-308. [CrossRef]

78. Campioli, E.; Duong, T.B.; Deschamps, F.; Papadopoulos, V. Cyclohexane-1,2-dicarboxylic acid diisononyl ester and metabolite effects on rat epididymal stromal vascular fraction differentiation of adipose tissue. Environ. Res. 2015, 140, 145-156. [CrossRef]

79. Watkins, A.M.; Wood, C.R.; Lin, M.T.; Abbott, B.D. The effects of perfluorinated chemicals on adipocyte differentiation in vitro. Mol. Cell. Endocrinol. 2015, 400, 90-101. [CrossRef]

80. Bastos Sales, L.; Kamstra, J.H.; Cenijn, P.H.; van Rijt, L.S.; Hamers, T.; Legler, J. Effects of Endocrine Disrupting Chemicals on in vitro global DNA methylation and adipocyte differentiation. Toxicol. Vitr. 2013, 27, 1634-1643. [CrossRef]

81. Guo, L.-W.; Wu, Q.; Green, B.; Nolen, G.; Shi, L.; LoSurdo, J.; Deng, H.; Bauer, S.; Fang, J.-L.; Ning, B. Cytotoxicity and inhibitory effects of low-concentration triclosan on adipogenic differentiation of human mesenchymal stem cells. Toxicol. Appl. Pharmacol. 2012, 262, 117-123. [CrossRef]

82. Schmid, B.; Rippmann, J.F.; Tadayyon, M.; Hamilton, B.S. Inhibition of fatty acid synthase prevents preadipocyte differentiation. Biochem. Biophys. Res. Commun. 2005, 328, 1073-1082. [CrossRef]

83. Yueh, M.-F.; He, F.; Chen, C.; Vu, C.; Tripathi, A.; Knight, R.; Karin, M.; Chen, S.; Tukey, R.H. Triclosan leads to dysregulation of the metabolic regulator FGF21 exacerbating high fat diet-induced nonalcoholic fatty liver disease. Proc. Natl. Acad. Sci. USA 2020, 117, 31259-31266. [CrossRef] [PubMed]

84. Noer, A.; Sørensen, A.L.; Boquest, A.C.; Collas, P. Stable CpG Hypomethylation of Adipogenic Promoters in Freshly Isolated, Cultured, and Differentiated Mesenchymal Stem Cells from Adipose Tissue. MBoC 2006, 17, 3543-3556. [CrossRef] [PubMed]

85. Fujiki, K.; Kano, F.; Shiota, K.; Murata, M. Expression of the peroxisome proliferator activated receptor $\gamma$ gene is repressed by DNA methylation in visceral adipose tissue of mouse models of diabetes. BMC Biol. 2009, 7, 38. [CrossRef]

86. Almamun, M.; Kholod, O.; Stuckel, A.J.; Levinson, B.T.; Johnson, N.T.; Arthur, G.L.; Davis, J.W.; Taylor, K.H. Inferring a role for methylation of intergenic DNA in the regulation of genes aberrantly expressed in precursor B-cell acute lymphoblastic leukemia. Leuk. Lymphoma 2017, 58, 2156-2164. [CrossRef] [PubMed]

87. Weinberg, D.N.; Papillon-Cavanagh, S.; Chen, H.; Yue, Y.; Chen, X.; Rajagopalan, K.N.; Horth, C.; McGuire, J.T.; Xu, X.; Nikbakht, H.; et al. H3K36me2 recruits DNMT3A and shapes the intergenic DNA methylation landscape. Nature 2019, 573, 281-286. [CrossRef] [PubMed] 
88. van den Dungen, M.W.; Murk, A.J.; Kok, D.E.; Steegenga, W.T. Persistent organic pollutants alter DNA methylation during human adipocyte differentiation. Toxicol. Vitr. 2017, 40, 79-87. [CrossRef]

89. Liu, Y.; Duong, W.; Krawczyk, C.; Bretschneider, N.; Borbély, G.; Varshney, M.; Zinser, C.; Schär, P.; Rüegg, J. Oestrogen receptor $\beta$ regulates epigenetic patterns at specific genomic loci through interaction with thymine DNA glycosylase. Epigenet. Chromatin 2016, 9, 7. [CrossRef]

90. He, Y.-F.; Li, B.-Z.; Li, Z.; Liu, P.; Wang, Y.; Tang, Q.; Ding, J.; Jia, Y.; Chen, Z.; Li, L.; et al. Tet-Mediated Formation of 5-Carboxylcytosine and Its Excision by TDG in Mammalian DNA. Science 2011, 333, 1303-1307. [CrossRef]

91. Cortázar, D.; Kunz, C.; Saito, Y.; Steinacher, R.; Schär, P. The enigmatic thymine DNA glycosylase. DNA Repair 2007, 6, 489-504. [CrossRef]

92. Vandenberg, L.N.; Colborn, T.; Hayes, T.B.; Heindel, J.J.; Jacobs, D.R.; Lee, D.-H.; Shioda, T.; Soto, A.M.; vom Saal, F.S.; Welshons, W.V.; et al. Hormones and Endocrine-Disrupting Chemicals: Low-Dose Effects and Nonmonotonic Dose Responses. Endocr. Rev. 2012, 33, 378-455. [CrossRef]

93. Rhomberg, L.R.; Goodman, J.E. Low-dose effects and nonmonotonic dose-responses of Endocrine Disrupting Chemicals: Has the case been made? Regul. Toxicol. Pharmacol. 2012, 64, 130-133. [CrossRef] [PubMed]

94. Gore-Panter, S.R.; Hsu, J.; Barnard, J.; Moravec, C.S.; Van Wagoner, D.R.; Chung, M.K.; Smith, J.D. PANCR, the PITX2 Adjacent Noncoding RNA, Is Expressed in Human Left Atria and Regulates PITX2c Expression. Circ. Arrhythm. Electrophysiol. 2016, 9, e003197. [CrossRef] [PubMed]

95. Okubo, T.; Hayashi, R.; Shibata, S.; Kudo, Y.; Ishikawa, Y.; Inoue, S.; Kobayashi, Y.; Honda, A.; Honma, Y.; Kawasaki, S.; et al. Generation and validation of a PITX2-EGFP reporter line of human induced pluripotent stem cells enables isolation of periocular mesenchymal cells. J. Biol. Chem. 2020, 295, 3456-3465. [CrossRef] [PubMed]

96. Long, J.Z.; Svensson, K.J.; Bateman, L.A.; Lin, H.; Kamenecka, T.; Lokurkar, I.A.; Lou, J.; Rao, R.R.; Chang, M.R.; Jedrychowski, M.P.; et al. The secreted enzyme PM20D1 regulates lipidated amino acid uncouplers of mitochondria. Cell 2016, 166, 424-435. [CrossRef] [PubMed]

97. Sanchez-Mut, J.V.; Heyn, H.; Silva, B.A.; Dixsaut, L.; Garcia-Esparcia, P.; Vidal, E.; Sayols, S.; Glauser, L.; Monteagudo-Sánchez, A.; Perez-Tur, J.; et al. PM20D1 is a quantitative trait locus associated with Alzheimer's disease. Nat. Med. 2018, 24, 598-603. [CrossRef] [PubMed]

98. Wang, Q.; Chen, Y.; Readhead, B.; Chen, K.; Su, Y.; Reiman, E.M.; Dudley, J.T. Longitudinal data in peripheral blood confirm that PM20D1 is a quantitative trait locus (QTL) for Alzheimer's disease and implicate its dynamic role in disease progression. Clin. Epigenet. 2020, 12, 189. [CrossRef]

99. Haworth, K.E.; Farrell, W.E.; Emes, R.D.; Ismail, K.M.; Carroll, W.D.; Hubball, E.; Rooney, A.; Yates, A.M.; Mein, C.; Fryer, A.A. Methylation of the FGFR2 gene is associated with high birth weight centile in humans. Epigenomics 2014, 6, 477-491. [CrossRef]

100. Bai, Y.; Fang, N.; Gu, T.; Kang, Y.; Wu, J.; Yang, D.; Zhang, H.; Suo, Z.; Ji, S. HOXA11 gene is hypermethylation and aberrant expression in gastric cancer. Cancer Cell Int. 2014, 14, 79. [CrossRef]

101. Parrillo, L.; Costa, V.; Raciti, G.A.; Longo, M.; Spinelli, R.; Esposito, R.; Nigro, C.; Vastolo, V.; Desiderio, A.; Zatterale, F.; et al. Hoxa5 undergoes dynamic DNA methylation and transcriptional repression in the adipose tissue of mice exposed to high-fat diet. Int. J. Obes. 2016, 40, 929-937. [CrossRef]

102. Li, Q.; Chen, C.; Ren, X.; Sun, W. DNA methylation profiling identifies the HOXA11 gene as an early diagnostic and prognostic molecular marker in human lung adenocarcinoma. Oncotarget 2017, 8, 33100-33109. [CrossRef]

103. Xu, Y.; Wu, D.; Liu, J.; Ma, Z.; Hui, B.; Wang, J.; Chen, Y.; Wang, S.; Lian, Y.; Sun, L. Down-regulated Long Noncoding RNA HOXA11-AS affects trophoblast cell proliferation and migration by regulating RND3 and HOXA7 expression in preeclampsia. BioRxiv 2018, 12, 195-206. [CrossRef]

104. Day, S.E.; Coletta, R.L.; Kim, J.Y.; Garcia, L.A.; Campbell, L.E.; Benjamin, T.R.; Roust, L.R.; De Filippis, E.A.; Mandarino, L.J.; Coletta, D.K. Potential epigenetic biomarkers of obesity-related insulin resistance in human whole-blood. Epigenetics 2017, 12, 254-263. [CrossRef] [PubMed]

105. Gudbjartsson, D.F.; Arnar, D.O.; Helgadottir, A.; Gretarsdottir, S.; Holm, H.; Sigurdsson, A.; Jonasdottir, A.; Baker, A.; Thorleifsson, G.; Kristjansson, K.; et al. Variants conferring risk of atrial fibrillation on chromosome 4q25. Nature 2007, 448, 353-357. [CrossRef] [PubMed]

106. Franco, D.; Campione, M. The role of Pitx2 during cardiac development. Linking left-right signaling and congenital heart diseases. Trends Cardiovasc. Med. 2003, 13, 157-163. [CrossRef]

107. Larsson, S.C.; Drca, N.; Jensen-Urstad, M.; Wolk, A. Incidence of atrial fibrillation in relation to birth weight and preterm birth. Int. J. Cardiol. 2015, 178, 149-152. [CrossRef] [PubMed]

108. Xiao, X.; Qi, W.; Clark, J.M.; Park, Y. Permethrin potentiates adipogenesis via intracellular calcium and endoplasmic reticulum stress-mediated mechanisms in 3T3-L1 adipocytes. Food Chem. Toxicol. 2017, 109, 123-129. [CrossRef]

109. Rüegg, J.; Cai, W.; Karimi, M.; Kiss, N.B.; Swedenborg, E.; Larsson, C.; Ekström, T.J.; Pongratz, I. Epigenetic Regulation of Glucose Transporter 4 by Estrogen Receptor $\beta$. Mol. Endocrinol. 2011, 25, 2017-2028. [CrossRef]

110. Bornehag, C.-G.; Moniruzzaman, S.; Larsson, M.; Lindström, C.B.; Hasselgren, M.; Bodin, A.; von Kobyletzkic, L.B.; Carlstedt, F.; Lundin, F.; Nånberg, E.; et al. The SELMA Study: A Birth Cohort Study in Sweden Following More Than 2000 Mother-Child Pairs. Paediatr. Perinat. Epidemiol. 2012, 26, 456-467. [CrossRef] 
111. Carrico, C.; Gennings, C.; Wheeler, D.C.; Factor-Litvak, P. Characterization of Weighted Quantile Sum Regression for Highly Correlated Data in a Risk Analysis Setting. JABES 2015, 20, 100-120. [CrossRef]

112. Koch, H.M.; Becker, K.; Wittassek, M.; Seiwert, M.; Angerer, J.; Kolossa-Gehring, M. Di-n-butylphthalate and butylbenzylphthalate-urinary metabolite levels and estimated daily intakes: Pilot study for the German Environmental Survey on children. J. Expo. Sci. Environ. Epidemiol. 2007, 17, 378-387. [CrossRef]

113. Fromme, H.; Schlummer, M.; Möller, A.; Gruber, L.; Wolz, G.; Ungewiss, J.; Böhmer, S.; Dekant, W.; Mayer, R.; Liebl, B.; et al. Exposure of an Adult Population to Perfluorinated Substances Using Duplicate Diet Portions and Biomonitoring Data. Environ. Sci. Technol. 2007, 41, 7928-7933. [CrossRef] [PubMed]

114. Vemuri, M.C.; Chase, L.G.; Rao, M.S. Mesenchymal Stem Cell Assays and Applications. In Mesenchymal Stem Cell Assays and Applications. Methods in Molecular Biology (Methods and Protocols); Vemuri, M., Chase, L., Rao, M., Eds.; Humana Press: Totowa, NJ, USA, 2011; p. 698. [CrossRef]

115. Bibikova, M.; Lin, Z.; Zhou, L.; Chudin, E.; Garcia, E.W.; Wu, B.; Doucet, D.; Thomas, N.J.; Wang, Y.; Vollmer, E.; et al. High-throughput DNA methylation profiling using universal bead arrays. Genome. Res. 2006, 16, 383-393. [CrossRef] [PubMed]

116. Du, P.; Zhang, X.; Huang, C.-C.; Jafari, N.; Kibbe, W.A.; Hou, L.; Lin, S.M. Comparison of Beta-value and M-value methods for quantifying methylation levels by microarray analysis. BMC Bioinform. 2010, 11, 587. [CrossRef] [PubMed]

117. Wickham, H. Toolbox. In ggplot2: Elegant Graphics for Data Analysis; Wickham, H., Ed.; Springer: New York, NY, USA, 2009; pp. 65-90, ISBN 978-0-387-98141-3.

118. Jaffe, A.E.; Murakami, P.; Lee, H.; Leek, J.T.; Fallin, M.D.; Feinberg, A.P.; Irizarry, R.A. Bump hunting to identify differentially methylated regions in epigenetic epidemiology studies. Int. J. Epidemiol. 2012, 41, 200-209. [CrossRef] [PubMed]

119. Campagna, M.P.; Xavier, A.; Lechner-Scott, J.; Maltby, V.; Scott, R.J.; Butzkueven, H.; Jokubaitis, V.G.; Lea, R.A. Epigenome-wide association studies: Current knowledge, strategies and recommendations. Clin. Epigenet. 2021, 13, 214. [CrossRef] [PubMed]

120. Lent, S.; Xu, H.; Wang, L.; Wang, Z.; Sarnowski, C.; Hivert, M.-F.; Dupuis, J. Comparison of novel and existing methods for detecting differentially methylated regions. BMC Genet. 2018, 19, 84. [CrossRef] 